INTERNATIONAL MONETARY FUND

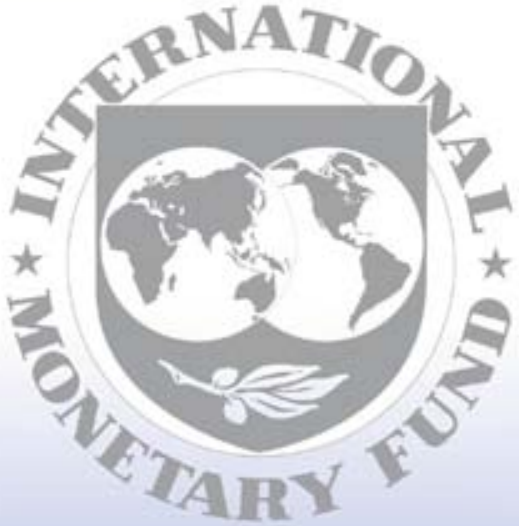

Staff

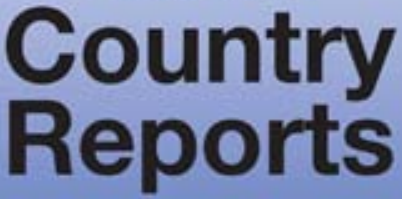


C1999 International Monetary Fund

June 19991999

IMF Staff Country Report No. 99/50

\title{
Albania: Staff Report for the 1999 Article IV Consultation, Request for the Second Annual Arrangement Under the Enhanced Structural Adjustment Facility, and Request for Augmentation
}

This report was prepared by a staff team of the International Monetary Fund following discussions with the officials of Albania on economic developments and policies. The report was then considered by the IMF's Executive Board in the context of the IMF's periodic consultation with Albania, as required under Article IV of the IMF Articles of Agreement. The views expressed in the staff report itself are those of the staff team and do not necessarily reflect the views of the Executive Board of the IMF or of the authorities of Albania; a supplementary statement by IMF staff may also be included. The views of the Executive Board as expressed in the discussion of the Article IV consultation report and as summarized in a Press Information Notice (PIN) are also included. In addition, a statement by the member country authorities may be appended. Further background documentation prepared by IMF staff for the consultation may be published separately at a later date.

This Article IV staff report is published--both in hard copy and on the IMF's website (http://www.imf.org) - as part of a pilot project. To assist the IMF in evaluating the pilot project for release of Article IV staff reports, reader comments on the staff report are invited prior to October 5, 2000, and may be sent by e-mail to Pilotproject@imf.org.

\footnotetext{
Copies of this report are available to the public from

International Monetary Fund - Publication Services 700 19th Street, N.W. - Washington, D.C. 20431

Telephone: (202) 623-7430 • Telefax: (202) 623-7201

Telex (RCA): 248331 IMF UR

B-mail: publications@imf.org

Internet: http://www.imf.org

Price: $\$ 15.00$ a copy
}

\author{
International Monetary Fund \\ Washington, D.C.
}




\title{
INTERNATIONAL MONETARY FUND
}

\author{
ALBANIA \\ Staff Report for the 1999 Article IV Consultation, Request for the Second \\ Annual Arrangement Under the Enhanced Structural Adjustment \\ Facility, and Request for Augmentation \\ Prepared by European I Department \\ (In consultation with other departments) \\ Approved by Martin Hardy and G. Russell Kincaid
}

May 28, 1999

Contents

Page

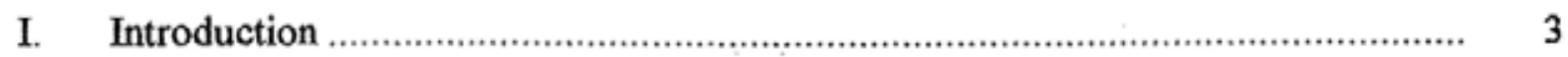

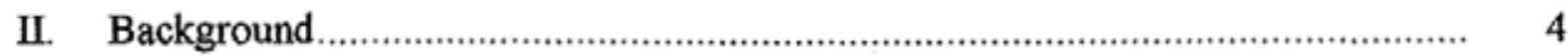

III. The Policy Discussions ............................................................................... 7

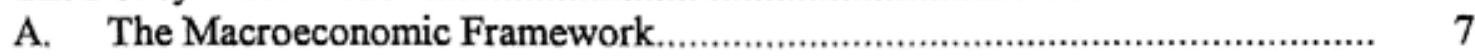

B. $\quad$ Fiscal Policy ...................................................................................

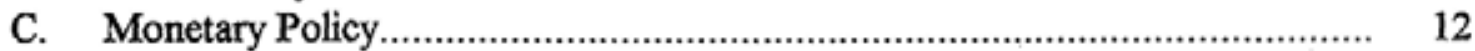

D. Structural Policies ................................................................................. 16

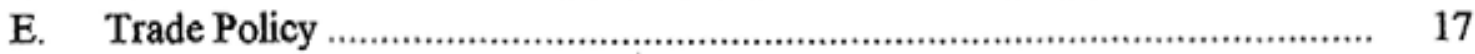

\begin{tabular}{lll}
\hline F. $\quad$ External Outlook and Capacity to Repay the Fund ..................................... & 18 \\
\hline
\end{tabular}

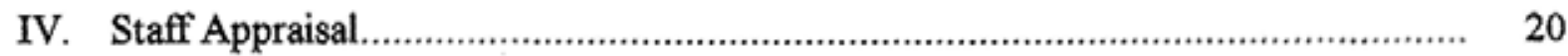

Text Boxes

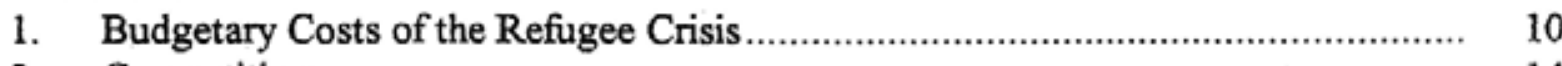

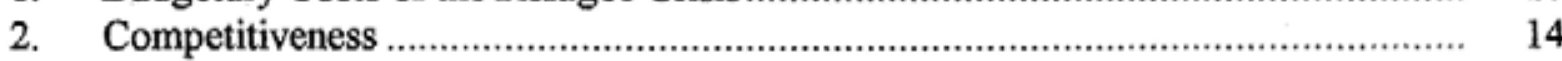

Figures

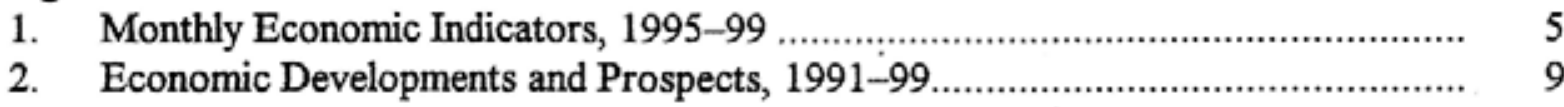

CInternational Monetary Fund. Not for Redistribution 
Tables

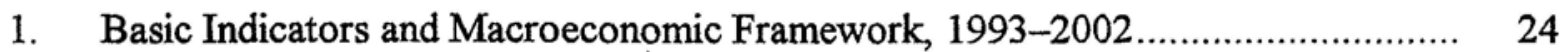

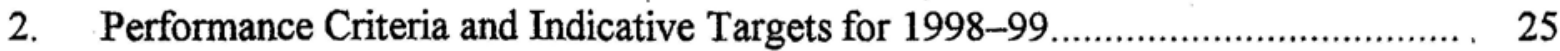

3. Prior Actions, Structural Performance, Criteria, and Structural Benchmarks

Under the First Annual ESAF Arrangement......................................... 26

4. $\quad$ Government Revenue and Expenditure, 1995-99 ......................................... 29

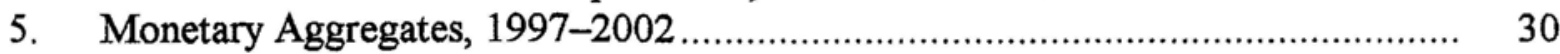

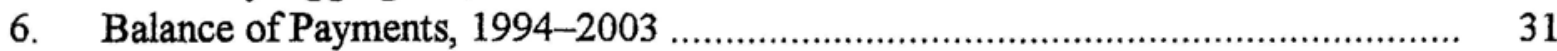

7. $\quad$ Projected Payments to the Fund as at April 1999 ........................................ 32

Appendices

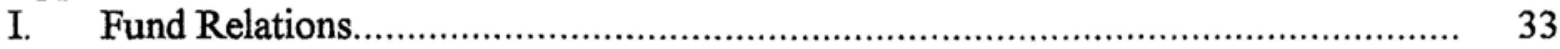

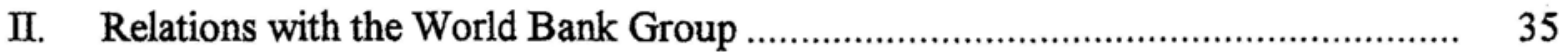

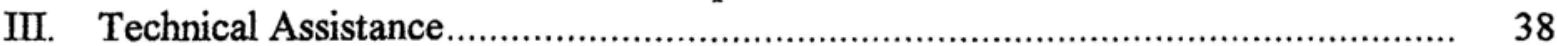

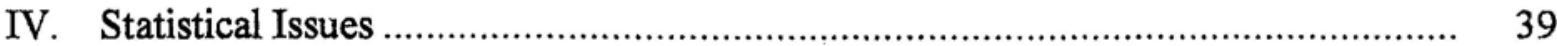

V. Second Annual Arrangement Under the Enhanced Structural Adjustment

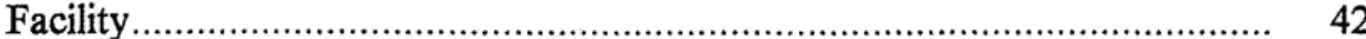

Appendix Table

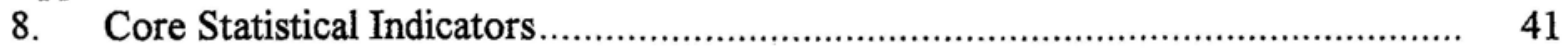

Attachment

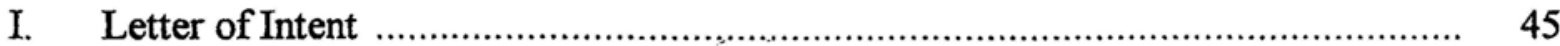

Attachment Tables

1. Performance Criteria and Indicative Targets for 1999-2000 ........................... 59

2. Prior Actions, Structural Performance Criteria, and Structural Benchmarks

for the Second Annual ESAF Arrangement 


\section{INTRODUCTION}

1. The discussions on the 1999 Article IV consultation and the proposed program to be supported under a second annual ESAF arrangement were held in Tirana, March 3-18, 1999, and were continued in Washington in April during the Spring meetings. ${ }^{1}$ The latter discussions focused primarily on the economic consequences of the crisis in neighboring Kosovo, which erupted on March 24 when the NATO campaign against the Federal Republic of Yugoslavia began.

2. Attachment I contains the authorities' request for a second annual ESAF arrangement to continue support for their economic program for April 1998-March 2001. The first annual arrangement was approved on May 13, 1998 and the review of the first-year program was concluded on January 27, 1999. One third of the SDR 35.3 million (72 percent of Albania's quota) available under the arrangement has been disbursed. In view of the increased balance of payments need arising from the impact of the Kosovo crisis, the authorities are requesting that access under the second annual arrangement be augmented by SDR 9.74 million (20 percent of quota). The authorities' medium-term economic program is described in the updated Policy Framework Paper (EBD/99/65, 5/28/99). The World Bank also has a broad program of support for Albania and in May 1999 approved a Public Expenditure Support Credit in the amount of US\$30 million. World Bank Board approval for a US\$45 million multi-sector Structural Adjustment Credit (SAC) will be sought in June. Appendices I and II summarize, respectively, relations with the IMF and World Bank. Appendix III describes main areas of technical assistance being provided to Albania.

3. At the Board meeting for the 1998 Article IV consultation (EBM/98/52, May 13, 1998), Executive Directors commended the authorities for their conduct of macroeconomic policies, but emphasized that sustaining high growth would require firm implementation of structural reforms and improved governance. Directors reiterated these comments at the more recent Board meeting to review the first annual ESAF arrangement.

4. The timeliness and quality of the data are only minimally sufficient in many areas for surveillance and program monitoring ${ }^{2}$, with the most notable deficiencies in the national accounts (Appendix IV). The authorities are, however, implementing a comprehensive work program, devised in collaboration with STA, to address the main statistical deficiencies. A key step in the

\footnotetext{
${ }^{1}$ The staff team for the discussions comprised Messrs. Corker (head), Jarvis, Samiei, and Rother (all EU1), Ms. Tamirisa (PDR), and Ms. Ricasa (Administrative Assistant, EU1). It was assisted by the resident representative, Mr. Treichel. Mr. Faini (Executive Director) attended the concluding meetings in Tirana. The mission met with Prime Minister Majko, Finance Minister Angjeli, Bank of Albania Governor Çani, and other key Ministers and officials.

${ }^{2}$ Program monitoring is described in paragraph 34 of Attachment II.
} 
work program is designated as a structural benchmark under the proposed ESAF-supported program. The authorities also intend to participate in the GDDS.

5. Albania maintains restrictions subject to Fund approval under Article VIII, Section 2(a), in the form of outstanding debit balances on inoperative bilateral payments agreements.

\section{BACKGROUND}

6. Since 1991, when 45 years of isolationist communist rule came to an end, Albania's economy has ridden a roller coaster. The economy initially collapsed, enjoyed robust recovery, and then tumbled again in 1997 as pyramid scheme bubbles burst, taking with them a large portion of personal savings and fomenting near civil war. Albania was putting this recent episode behind it when, in March 1999, the crisis in Kosovo erupted, precipitating a tide of refugees into Albania. The refugees are placing considerable strain on the social and economic infrastructure and on the budget and balance of payments. Without sufficient external budgetary assistance on appropriate terms, Albania's macroeconomic stability and reform program could be compromised.

7. Prior to the Kosovo crisis, macroeconomic stability had been restored and economic trends were highly encouraging. During 1998 , the government adhered to its tight fiscal target, reducing the domestically financed component of the deficit to 6.4 percent of GDP in 1998 from 10.8 percent of GDP in 1997 through a combination of revenue enhancing measures and control over the growth of primary expenditures. The domestic fiscal effort supported the goals of monetary policy and end-1998 inflation declined to 8.7 percent compared to the target of 10 percent and to 42 percent during 1997 (Figure 1). In conjunction with a sharp rebound in private transfers, it also contributed to a halving of the external current account deficit from 12 percent of GDP in 1997 to 6 percent of GDP, enabling foreign reserves to climb to a comfortable 4.7 months of imports of goods and services at end-1998. ${ }^{3}$ Confidence in policies was reflected in a recovery in the lek, which had fallen by about 30 percent in nominal effective terms during the 1997 crisis. The lek appreciated by about 25 percent during the second half of 1997 and has since been broadly stable. In an environment of improving macroeconomic and domestic political stability, growth is estimated to have been 8 percent in 1998, thereby reversing the 1997 decline in output (Table 1). Policies remained consistent with agreed indicative targets in the first quarter of 1999 and annual inflation fell further to just 2 percent in March (Table 2).

8. The authorities' wide-ranging reform program was also broadly on track (Table 3). A first priority had been to clean up the mess created by the pyramid schemes. By March 1999, substantial progress had been achieved and the foreign administrators had made an initial offering

\footnotetext{
${ }^{3}$ Estimates of the current account deficit are subject to wide margins of error. In particular, smuggling and customs fraud add considerably to the misreporting of trade flows, while private transfers are inaccurately estimated.
} 
Figure 1. Albania: Monthly Economic Indicators, 1995-99
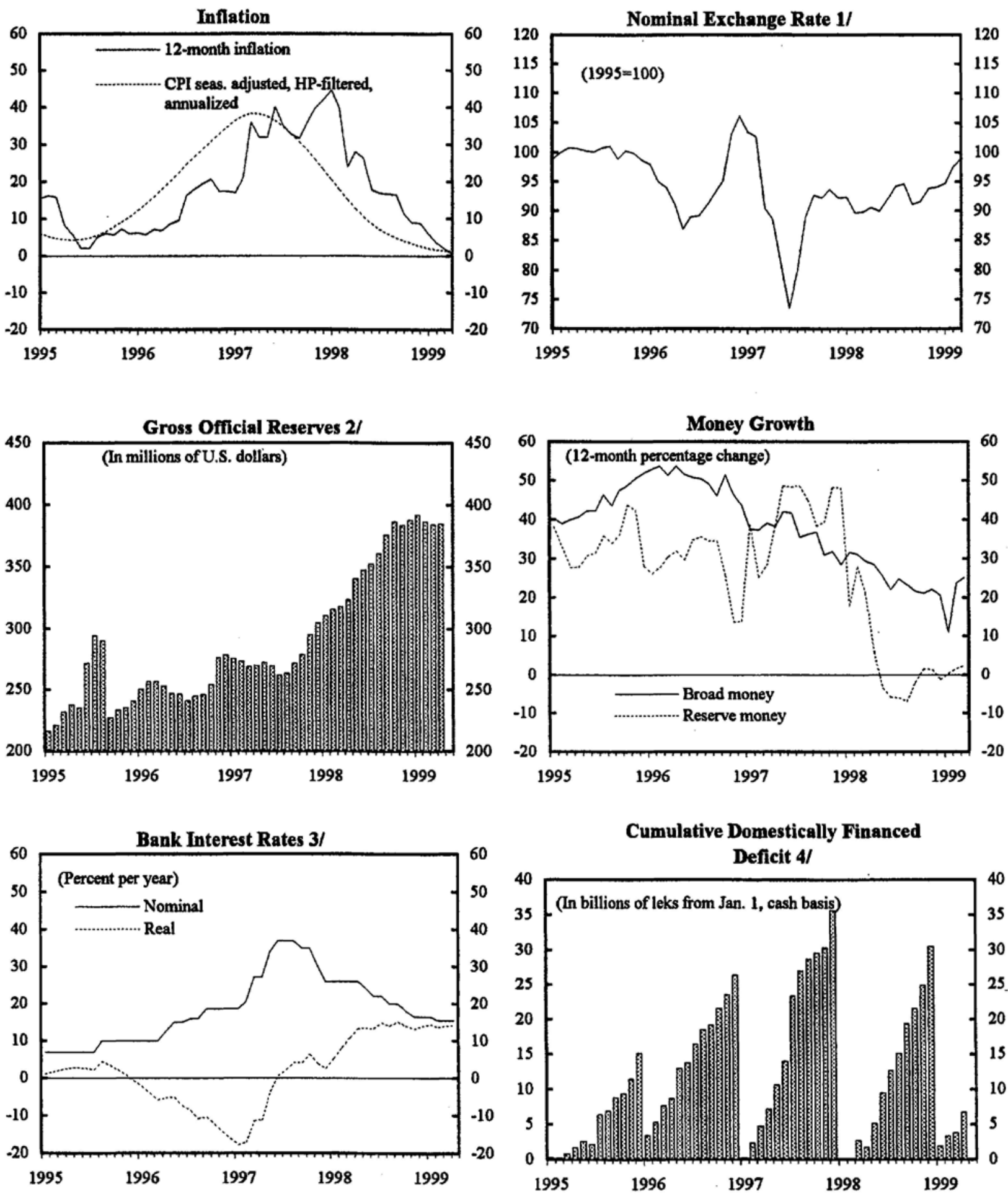

Source: Bank of Albania, Ministry of Finance, INSTAT, and Fund staff estimates.

1/ Against the currencies of Albania's major trading partners. A rise in the graph indicates appreciation.

2/ The decline in September 1995 reflects payments associated with rescheduling of Albania's commercial bank debt.

3/ Three-month deposit rate; the real rate is the nominal rate minus annualized inflation, as depicted above.

4/ Preliminary estimates based on Bank of Albania and Social Insurance Institute data. 
for sale of the assets of the pyramid scheme companies and turned over the remaining tasks to local administrators. At the same time, the authorities made progress in developing the formal financial system, preparing the National Commercial Bank (NCB) for privatization and placing the Savings Bank under a foreign governance contract. Enterprise privatization also advanced, with a further 450 small- and medium-sized enterprises (SMEs) being privatized between the beginning of 1998 and March 1999, and one of the four remaining enterprises formerly under the Enterprise Restructuring Agency (ERA) being leased to a foreign investor. In the agricultural sector, where land is in private hands but holdings are fragmented, progress in developing the land market has continued with land registration and land sales transactions proceeding in line with program targets. In the public administration, overmanning was reduced through cuts in employment of about 10 percent between the beginning of 1998 and March 1999. And, in tax administration, a revised customs code was prepared, although its implementation was delayed when Parliament considerably watered down key elements. The customs code was resubmitted to Parliament in March 1999. Finally, to address more general governance issues, the government drew up and began implementing an anti-corruption strategy. ${ }^{4}$

\section{The Kosovo crisis adds new challenges to the authorities' ability to maintain} macroeconomic stability and pursue their reform program. By mid-May, about 430,000 largely destitute refugees had flooded into Albania, augmenting the local population by some 13 percent. More than half of the refugees have been given shelter in private homes, the rest are in camps or hastily converted warehouses. The sheer number of refugees places a considerable strain on the social and economic infrastructure as well as on the budget, not least because international relief agencies have been overwhelmed by the speed at which the refugee crisis has evolved. At the same time, humanitarian and military supplies have clogged Albania's ports, crowding out commercial (and taxable) imports. So far, the refugees have been provided with a warm welcome. However, the initial unifying impact of the crisis on fractious domestic political rivalries is already starting to fray. ${ }^{5}$

10. Nevertheless, reform and economic stabilization efforts are continuing. With the budget facing large, uncertain costs associated with the refugees, the government announced a freeze on public investment spending and a postponement of the 10 percent civil service pay rise planned for April 1. Spending restrictions were lifted only when the international community began to make firm pledges of budgetary assistance. ${ }^{6}$ The exchange rate has remained relatively stable with a 3-4 percent depreciation in the first week of the crisis being subsequently reversed. At the same time, some important structural measures have been implemented: Parliament passed

${ }^{4}$ See EBS/99/2, January 8, 1999, Box 2 for more details on governance issues in Albania.

${ }^{5}$ The main opposition party has remained outside of Parliament following its defeat in the 1997 general election.

${ }^{6}$ The pay rise, for example, went into effect on May 1. 
the amended customs code; the government selected a buyer for NCB following the submission of two international tenders; and the government drafted decisions to close two more former-ERA enterprises.

11. The Kosovo crisis apart, Albania still faces tremendous development problems:

- Poverty is widespread. Despite rapid growth in the early years of transition (1993-96) Albania's average standard of living is among the lowest in Europe with per capita GNP only about US\$800.

- Basic structural deficiencies run deep. The financial system is rudimentary and does not put savings to their best use; the tax base is inadequate; communications are hampered by a dilapidated infrastructure; and waste and inefficiency are considerable in the public utilities.

- Corruption and organized crime are acknowledged problems and administrative capacity is weak. Tax collection is undermined by graft and essential regulations for market economy are often not enforced.

The internal and external security situation remains tenuous and undermines investor confidence. Firearms looted during the 1997 crisis continue to circulate and the rule of law is not well established in some regions. There is also a risk that the Kosovo crisis could develop into a broader regional conflict.

\section{THE Policy Discussions}

12. Albania's development needs call for the implementation of an ambitious and comprehensive structural reform program and a concerted attack on poor governance. Initial discussions focused on a review of the reform priorities that are being supported under the ESAF arrangement. After the Kosovo crisis broke, discussions turned to the steps necessary to maintain macroeconomic stability and the momentum of reforms. The authorities are well aware that the crisis creates both challenges to, and enhanced needs for, better governance and stronger administrative capacity.

\section{A. The Macroeconomic Framework}

\section{Assuming refugee-related expenditures are largely financed by the international} community, the impact of the Kosovo crisis on growth and inflation is expected to be small. However, this is subject to a wide margin of uncertainty as described below. Albania, in contrast to some other affected countries in the region, has negligible official trade with or through the Federal Republic of Yugoslavia and supply disnuptions in the underdeveloped north of the country (which borders Kosovo) are likely to be offset by increased production incentives in other sectors. On the demand side, adverse confidence effects on local and foreign financed investment, and some switching by exporters to local markets, will lead to a shift from private investment and exports to consumption (public and private) and imports. On balance, the 8 percent growth 
projection for 1999, which appeared feasible before the crisis, has been retained (Figure 2). Some temporary increase in food prices (the dominant component of the CPI) may result from the crisis, but given the unexpectedly low inflation in the first quarter, such an increase is still expected to leave inflation below the 7 percent end-year target agreed at the time of review of the first-year ESAF-supported program.

14. Uncertainty about the outlook for growth and inflation has increased substantially. In particular, if the capacity problem of the ports is not solved, output could be adversely affected as humanitarian and military imports crowd out intermediate and capital goods imports; and additional demand from the refugees could leak into higher prices. More generally, the large (and growing) refugee population stretches the already-thin administrative capacity of the government, with attendant risks of a breakdown in law and order and social stability.

15. The uncertainty is magnified for projections beyond 1999, not least because it is unclear how the conflict will be resolved. Assuming the refugees return home in early 2000, that foreign direct investment resumes, and fiscal consolidation and structural reforms continue as programmed, the medium-term scenario would not be significantly different from that envisaged at the beginning of the ESAF arrangement. Growth would average 7-8 percent per year, while inflation stabilizes at industrial country levels. If the crisis is prolonged, there would be increased risk that law and order would break down, corruption rise, and structural reforms, including privatization, would be postponed. The need to absorb the refugees into the labor and housing markets could also be a source of friction, even though they would add to potential output.

\section{B. Fiscal Policy}

16. The authorities agreed that the key objective is to ensure that the Kosovo crisis does not interfere with underlying fiscal consolidation. For 1999 , the authorities plan to stick to their original budget goal of reducing the domestically financed deficit from $61 / 2$ percent of GDP in 1998 to $51 / 2$ percent of GDP in 1999 (Table 4). However, if cuts in essential development and social expenditures are to be avoided, this can only realistically be achieved if the international community finances the large budgetary cost of helping the refugees. For 2000, the authorities plan to reduce the domestically financed deficit to about 4 percent of GDP. Passage of a satisfactory budget would be a condition for completing the mid-year review of the ESAFsupported program.

\section{The budget gap resulting from the Kosovo crisis is estimated at US\$154 million} (4 percent of GDP) for 1999. The estimate, which is subject to a wide margin of uncertainty, almost entirely reflects expenditures related to the refugees. These expenditures are in addition to those being financed directly by the international relief agencies (Box 1). While it is assumed that

\footnotetext{
${ }^{7}$ No signs of inflationary pressures were visible in April, the first full month of the crisis. Food price rises were negligible and 12-month CPI inflation fell to 0.4 percent.
} 
Figure 2. Albania: Economic Developments and Prospects, 1991-1999 1/
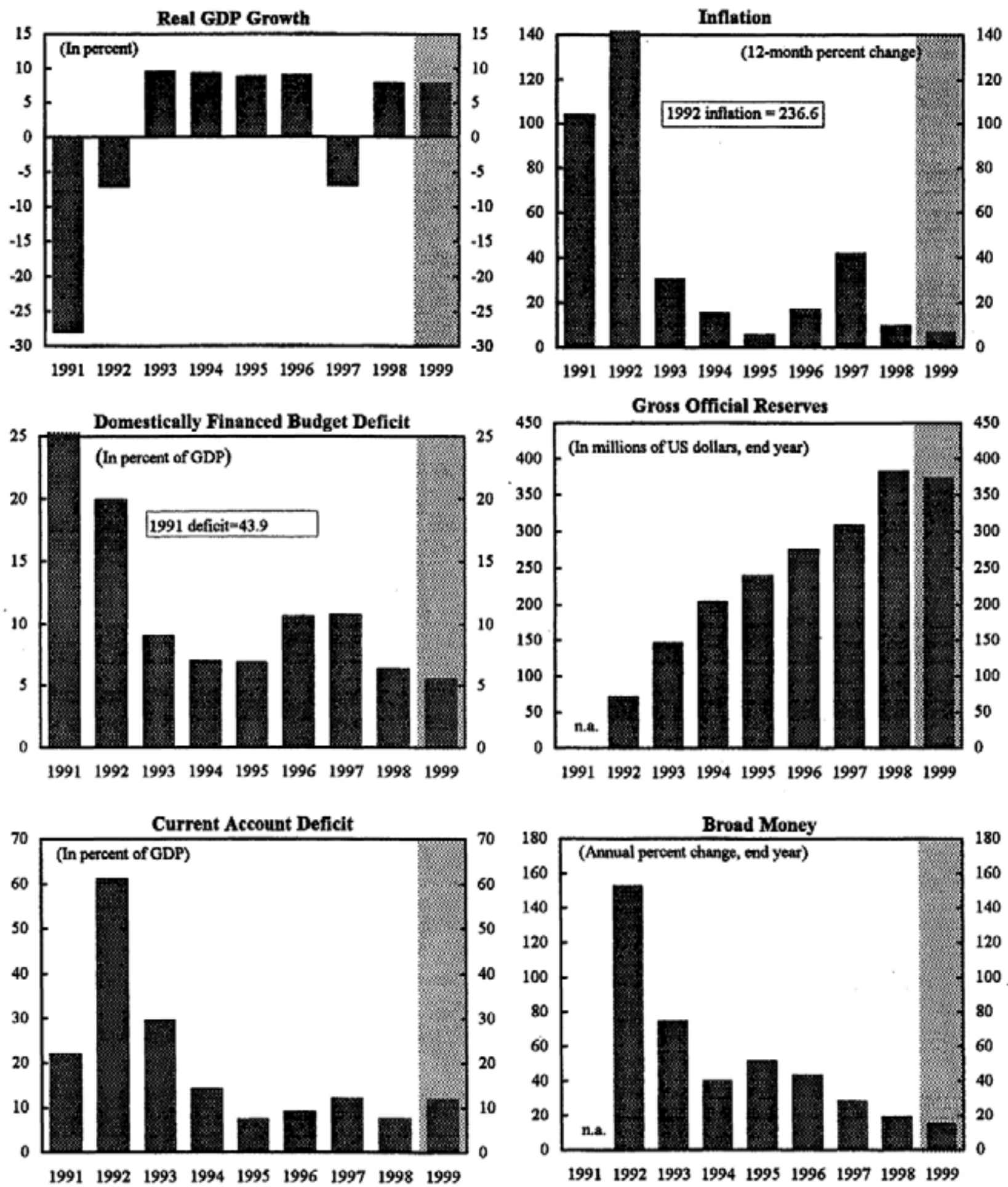

Source: Albanian authorities and Fund staff estimates.

1/ Estimates for 1998, program projections for 1999. 


\section{Box 1. Albania: Budgetary Costs of the Refugee Crisis}

The Kosovo crisis imposes substantial spending pressure on the Albanian budget because the international relief agencies do not cover all the costs of the refugees and, at least initially, were not able to cope fully with even the refugees' subsistence needs. The projected budgetary costs assume the number of refugees in Albania rises to some 500,000 in May and decreases gradually thereafter (see figure). Around 40 percent of the refugees are expected to stay in camps, while the remainder would live with Albanian families. Total budgetary expenditures are estimated at US\$144 million, or the equivalent of US\$33 per refugee per month (see table below). The main expenditure categories are as follows:

Refugee numbers (in thousands)

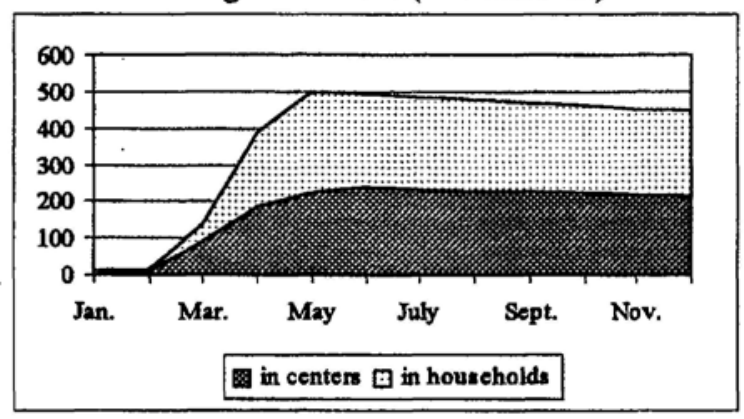

Social assistance expenditure of US $\$ 29$ million reflects monthly payments to households hosting refugees equivalent to US\$10 per refugee and a small one-time budgetary contribution of just US\$14 toward the subsistence of each refugee living in a center. The latter is potentially a sizable underestimation.

Estimated Budgetary Expenditures

\begin{tabular}{|c|c|c|c|c|c|c|c|}
\hline & $\begin{array}{c}\text { Social } \\
\text { assist. }\end{array}$ & Education & Health & Police & Defense & Other & Total \\
\hline $\begin{array}{c}\text { Total } \\
\text { (US\$ mill.) }\end{array}$ & 28.5 & 25.5 & 16.0 & 12.9 & 8.3 & 52.4 & 143.6 \\
\hline $\begin{array}{c}\text { Monthly per } \\
\text { refugee (US\$) }\end{array}$ & 6.6 & 5.9 & 3.7 & 3.0 & 1.9 & 12.2 & 33.3 \\
\hline
\end{tabular}

Education expenditure of US\$26 million allows for the continuation of school education for refugee children. The amount covers the costs for teaching, in particular financing a summer school program to compensate for lost education time, as well as necessary spending on school buildings, text books, and other equipment to cope with the increase in student numbers.

Health expenditure of US\$16 million provides for an average of $11 \frac{1}{2}$ hospital days per refugee as well as the cost for additional medical personnel outside hospitals and medicines and related spending on medical infrastructure. Relief organizations are assumed to provide basic medical care, including vaccination, to refugees in centers. Reflecting the poor state of health of the refugees and the predominance of old people, projected per capita health spending is more than twice that for the resident population.

Policing and defense expenditures of US\$21 million largely result from spending on overtime of security personnel given the need to police refugee camps and maintain the security forces on alert. This item also includes costs for registering refugees, who have been stripped of identity papers.

Other expenditures include the cost for infrastructure, in particular for roads to Albania's northern regions, provision of sanitation and electricity to refugee centers, and the cost of converting buildings to temporary accommodation. The estimate assumes that any additional infrastructure costs that would be incurred in winter months would be borne directly by relief agencies.

Taking into account the fixed costs of caring for the refugees, the budgetary cost would rise by US $\$ 27$ million if the average number of refugees were to be 100,000 higher than assumed. 
the refugees will not be repatriated before the end of the year, per capita cost estimates are on the conservative side. In particular, they assume that the potentially steep increase in subsistence costs that could occur when winter approaches will be met by the humanitarian aid agencies. Given the large number of displaced persons currently in Kosovo, the number of refugees in Albania could peak at well above the assumed level of 500,000. Revenue losses attributable to the initial log-jam in the ports is put at US\$10 million (2 percent of total taxes). Again, this could rise substantially if the problem of the clogged ports is not solved quickly. The authorities have asked for logistical assistance from NATO and bilateral donors.

18. The staff stressed the importance of ensuring transparent accounting for budgetary costs and external financial support connected with the Kosovo crisis. To this end, the authorities intend to draw up bi-monthly estimates of refugee-related expenditures and record them under a separate budget classification. Actual expenditures will be reported on a bi-weekly basis to the Ministry of Information and made available to the public and donor community. Financial aid donated to the government to cover humanitarian costs will be placed in a separate budgetary account in the Savings Bank.

\section{The staff also stressed that the Kosovo crisis should not weaken the authorities'} resolve to strengthen tax administration. A significant part of fiscal adjustment relies on improved collection efforts, including better enforcement of tax compliance under the new Profit and Income Tax Law and measures to reduce smuggling and customs fraud. ${ }^{8}$ The authorities acknowledged that, even before the onset of the Kosovo crisis, delays in implementing the new customs code and customs reference valuation file had put their tax collection efforts behind schedule. Nevertheless, they expected to get back on track in the second half of the year such that the total shortfall in revenues would be limited to the US\$10 million attributable to the Kosovo crisis. ${ }^{9}$ The staff insisted that implementation of key elements of the customs code as well as antismuggling measures be prior actions for Board consideration of the program. The authorities will also begin implementing a plan to collect customs debts by end-June and hire 60 additional antismuggling officers by the end of the year (structural benchmarks). Under the program, the staff will review tax collection on an ongoing basis with the authorities in order to identify weaknesses and agree, if necessary, on additional measures to strengthen tax compliance. Bearing in mind the difficulty in distinguishing between poor compliance and the economic consequences for revenue of the Kosovo crisis, the staff will liaise closely with the EU's customs advisory unit in Albania to gain an independent assessment of the authorities' efforts to strengthen governance.

\footnotetext{
${ }^{8}$ Part of the projected increase in taxes in 1999 of about $11 / 2$ percentage points of GDP also results from a new 10 percent withholding tax on interest income and from the full-year impact of the solidarity tax surcharge. These measures more than offset the impact of a sizable reduction in the unweighted average tariff rate.

${ }^{9} \mathrm{~A}$ mid-year increase in local property taxes and the imposition of excises on tires and cosmetic products will also make a small contribution to revenues.
} 
20. Tax collection efforts, in conjunction with expenditure discipline, are important to ensure that there are sufficient resources for public investment in 1999. On the expenditure side, the pay increase for budget sector workers will partly be financed by employment cuts, while the compilation of a comprehensive database for recipients will help to contain spending on social assistance through better targeting of benefits. Even so, the scope for higher public investment will be limited: investment financed by the budget is set to increase from 2.3 percent of GDP in 1998 to only 2.4 percent of GDP in $1999 .{ }^{10}$ The staff emphasized that it would be regrettable if failure to meet tax collection targets forced the authorities to scale back investment spending to keep within borrowing limits.

\section{Looking further ahead, the priority will be to broaden the income tax base if} sufficient resources are to be generated for spending on infrastructure, health, education, and social safety nets. While the authorities accept that present resources for health and education can be used more efficiently, overall spending in these sectors at 1.5 percent of GDP and 2.8 percent of GDP, respectively, is relatively low. Finding a means of taxing agriculture will be particularly important to generate new resources-although this will only be feasible once the process of land registration is completed, and probably not before 2001 . The medium-term projection assumes that the tax-GDP ratio rises from 13.6 percent in 1999 to 16.2 percent in 2002 and that non-interest expenditures stabilize at less than 18 percent of GDP (see Table 1). On the assumption that real interest rates decline from their currently high levels, interest expenditure falls sharply as a percentage of GDP and the debt ratio would be on a declining path.

\section{At the same time, reforms of the public administration and budget procedures will} be needed to ensure a well-motivated civil service and better expenditure planning. In particular, efforts to reduce over-staffing will continue: in 1999, abstracting from temporary positions created by the Kosovo crisis, the authorities plan to cut over 5,000 budget sector jobs (3.7 percent of the total) with some of the savings being used to increase wage differentiation (structural benchmark). Further measures to enhance efficiency in the public sector will be identified through functional reviews of the spending ministries. These have been slow getting started, but with technical assistance from the World Bank reviews in five key ministries are expected to be completed this year. Efforts to strengthen budget classification and planning and to improve cash management will also continue with technical assistance from the IMF and others. A World Bank public expenditure review is planned for 2000 .

\section{Monetary Policy}

23. The main objective of monetary policy for $\mathbf{1 9 9 9}$ is to maintain inflation at a low level. While monetary policy is in principle anchored on money growth, the authorities take a pragmatic approach that also takes into account developments in prices and the exchange rate

\footnotetext{
${ }^{10}$ Externally financed investment will increase from 2.9 percent of GDP in 1998 to 3.6 percent of GDP in 1999.
} 
when adjusting interest rates and credit ceilings. The sharp fall in inflation at the beginning of the year prompted the Bank of Albania to cut interest rates by $1 \frac{1}{2}$ percentage points. This still left interest rates highly positive in real terms (minimum deposit rates are currently 15 percent and inflation is negligible). In view of the uncertainty created by the Kosovo crisis, the Bank of Albania has, for now, put further rate cuts on hold. Nevertheless, if inflation remains below the target and the stability of the lek continues, scope would exist for interest rate cuts later in 1999. The staff noted that the case for rate cuts would strengthen if the lek were to appreciate further. While competitiveness is still viewed as adequate (see Box 2), the exchange rate has appreciated substantially in real terms since 1995 . The staff agreed that the authorities should continue to maintain a market-determined exchange rate system which has served Albania well in the past.

\section{At this stage, the Bank of Albania and the staff do not expect that the Kosovo crisis} will have a major impact on the monetary program in 1999. While the crisis may tilt the demand for money somewhat in favor of cash, overall demand for money is projected to grow broadly in line with nominal GDP, or by about 15 percent in the year to December (Table 5). There is also likely to be more foreign currency in circulation, although there are no signs so far of significant currency substitution. With virtually no change in NFA, domestic credit expansion would be sufficient to meet the demands of the budget-assuming Kosovo costs are externally financed-and allow for sizable growth in private sector credit; albeit from a small base. However, with an expansion in net credit by the two dominant state banks currently prohibited for prudential reasons, the programmed increase in private credit will only take place-and, more to the point, would only be desirable-if banking sector reforms are carried out quickly and supervision strengthened markedly.

\section{An important task for the Bank of Albania during 1999 will be to prepare the} ground for a move to indirect monetary policy instruments. Since early in the transition process, the main monetary instruments have been minimum deposit interest rates in the stateowned banks, which hold the great majority of deposits, and lending limits applied on all individual banks. The relevance of the former will disappear with the expected privatization of the remaining state-owned banks, and the Bank of Albania is keen to abolish lending limits on private banks-although strict limits on credit expansion would continue to apply to banks having a proportion of bad loans in excess of 20 percent. The staff supported the Bank of Albania's intentions, but stressed that development of the treasury bill market should be a precondition for ceasing to apply minimum interest rates, and that improvements in banking supervision are necessary before bank-by-bank lending limits are dropped. During 1999, MAE will be providing technical assistance on both on- and off-site supervision and to help the Bank of Albania upgrade its intervention techniques in the treasury bill market.

\section{Thanks to the passage of a revised Bank of Albania Law in late 1997 and of a} revised Banking Law in 1998, the legal framework for the financial sector is now generally good. Following incorporation of comments from LEG and MAE, the authorities intend to submit a draft law on Secured Transactions by end-June (structural benchmark). 


\section{Box 2. Albania: Competitiveness}

The continuing appreciation of the real CPZ-based effective exchange rate (REER) since the end of the civil disturbances in 1997 raises questions about Albania's underlying competitiveness. However, a preliminary assessment suggests that the real appreciation has not gone too far. While any analysis is very difficult in Albania's case given the short history of transition, the severity of recent external and internal shocks, and the many data deficiencies, the following facts support this view:

- The appreciation of the REER during 1998 does not appear to be notably out of line with past trends (Figure 3, top panel). Disregarding the period of instability connected with the pyramid schemes, the REER has been on an upward trend consistent with the scope for appreciation afforded by rapid productivity growth in the traded goods sector (in Albania's case, mainly agriculture). On the basis of the authorities' commitment to further structural reform, rapid productivity growth can be expected to continue.

- The relative price of nontradable to tradeable goods has remained fairly stable since the crisis and is significantly below pre-crisis levels (Figure 3, bottom panel). This suggests that the appreciation has not been accompanied by major incentives to shift resources away from the tradeable goods sector.

- Dollar wages in Albania remain very low and are below levels in other lowincome transition countries. Currently the gross average wage in the budget sector (more relevant wage data, unfortunately, are not available) is only US\$70 per month compared with US\$123 in Bulgaria, US\$117 in Romania, US\$213 in Lithuania, and US\$249 in Estonia.

- While the full lagged effects of the real appreciation will not yet have been felt, export growth showed no sign of weakening during the course of 1998. In the second half of 1998, exports were 32 percent higher than in the first half of the year. 
Figure 3. Albania: Competitiveness Indicators 1/

(1995=100)
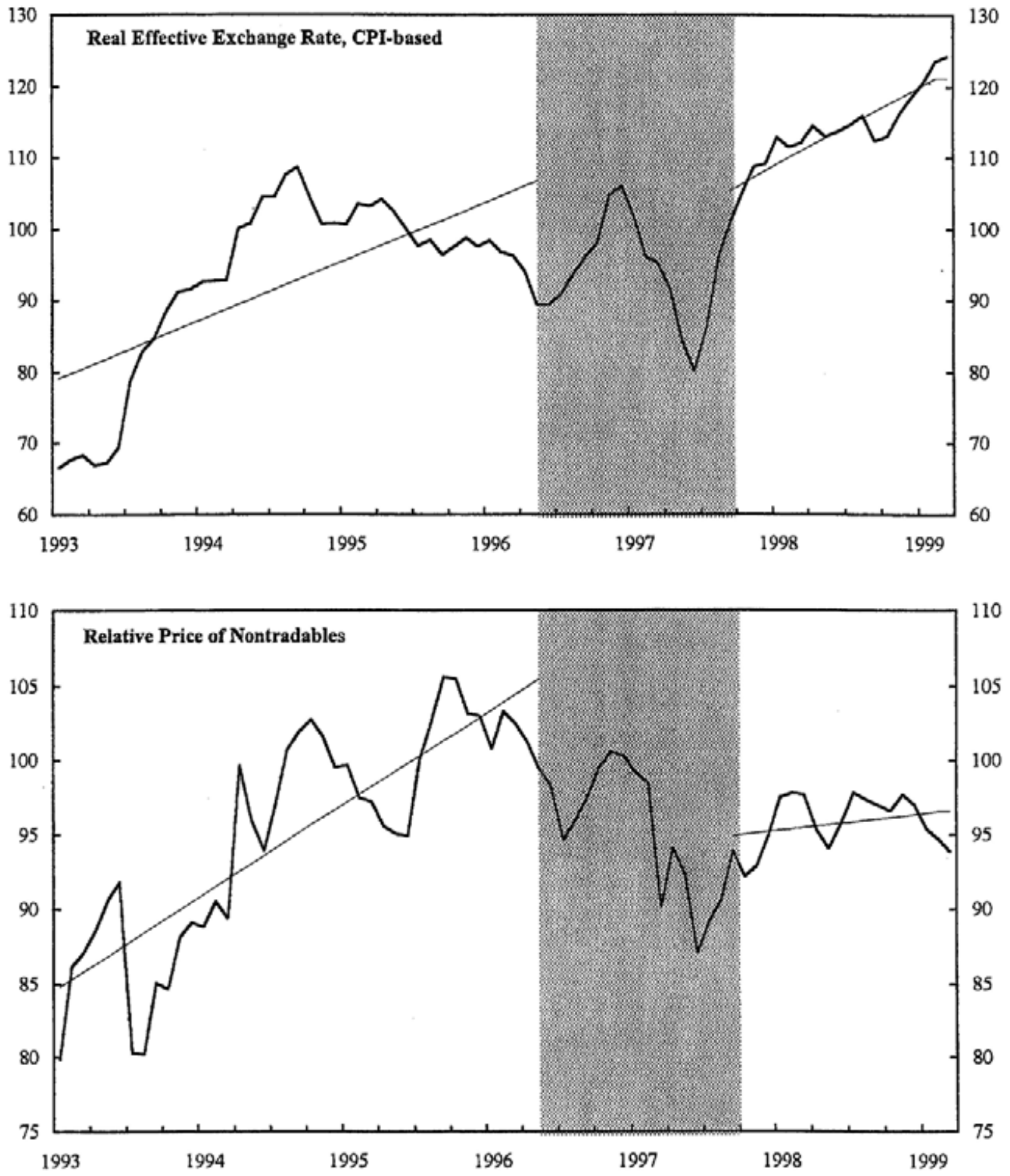

Source: Fund staff estimateş.

1/ Shaded area represents a period of nominal exchange rate instability associated with the pyramid schemes. 


\section{Structural Policies}

27. While accepting that the Kosovo crisis will divert the energies of key officials to the refugee problem, the staff stressed that it would be important to keep up the momentum of reforms. The authorities concurred, although they pointed out that factors beyond their control, such as reduced international investor confidence, could lead to some delays in the privatization program, while increased opportunities for corruption would make their efforts to strengthen governance more difficult. However, in most areas the authorities agreed that structural reform targets discussed with the staff before the Kosovo crisis remained feasible.

\section{Privatizing the two state-owned banks is a priority if a well-functioning financial} system is to be created. Since the authorities had selected a buyer for the NCB (prior action), the staff advised them to negotiate the terms of the sale rapidly and flexibly, while not offering concessions that could undermine the program (e.g. tax concessions, guaranteed access to Bank of Albania facilities). The authorities were also encouraged to expedite preparations for the sale of the more economically significant Savings Bank. Submission of the privatization law to Parliament is an end-September structural performance criterion under the program, with a view to initiating the privatization process in 1999 and selecting a buyer before end-March 2000 (structural benchmark). As an important first step, the staff suggested that the government put its financial relations with this bank on a clear commercial footing. In the meantime, the bank should continue to operate under the governance contract agreed with foreign advisors.

\section{Likewise, the steady progress in establishing a functioning land market should} continue. Agriculture is very important to the Albanian economy-it accounts for over 50 percent of GDP - and the consolidation of land holdings will be needed to engender further productivity gains. The proposed program contains targets for land registration and land transactions (structural benchmarks). The authorities will also ensure the provision of adequate office space for land registries.

\section{Although the Kosovo crisis could delay privatization of selected enterprises, the} preparation of strategic sectors for privatization should not be affected. The sale and liquidation of the former-ERA companies and small- and medium-sized enterprises has, after a drawn out process, largely been completed. ${ }^{11}$ Now the focus has shifted to the mining, oil, and telecommunications sectors. The authorities had hoped to jump start the privatization process in these strategic sectors with the early sale of the mobile telephone company, followed later in the year by the sale of the fixed telecommunications company. However, a quick sale is unlikely whilst Kosovo uncertainties predominate. In the other sectors, the authorities will use 1999 to

\footnotetext{
${ }^{11}$ The authorities expected to lease to a French company the only remaining ERA company in public hands in order to complete the prior action for the program. Negotiations had, however, been suspended when the Kosovo crisis broke. Selling or closing all but a handful of the remaining SMEs is an end-September structural performance criterion.
} 
carry out restructuring and to formulate their privatization strategies in conjunction with foreign advice. In the mining sector, the authorities intend to sell or liquidate all small copper and chromium mines by end-September (structural benchmark). In the oil sector, the state oil company (Albpetrol) has been split into three companies and employment will be reduced by 2,000 to 7,500 by end-March 2000 . In both sectors, the requisite privatization laws will be enacted by end-September (structural benchmarks).

\section{While privatization is a longer-term objective for the public utilities, stemming} losses and improving the performance of the state-owned electricity company, KESH, has become a priority. KESH's technical performance has now deteriorated to the point where power outages are the norm in many areas, impeding economic development. Losses due to electricity theft and payments arrears are pervasive and KESH's financial performance has become so bad that it threatens to become a drain on the budget. The staff urged the authorities to continue to work with the World Bank and foreign donors to address the management and associated governance issues. As a practical measure, the staff insisted that the government ensure that KESH install special meter boxes in apartments to help reduce fraud (structural benchmark).

32. Electricity theft is a symptom of a wider problem of respect for institutions. The staff thus welcomed the authorities' determination to strengthen governance in key areas, and in particular in the judiciary and the customs administration where the authorities are receiving technical assistance from the World Bank and the EU. In a related vein, the staff also urged the authorities to bring the pyramid scheme episode-which at root had been a governance problem-to full conclusion at the earliest possible date. Delaying the sale and distribution of remaining assets risked provoking a public that is having to accept a large financial loss. It would also be important to carry out these remaining tasks as transparently as possible.

\section{E. Trade Policy}

\section{Albania has made significant progress in establishing a liberal and open trade} system. In April, the authorities reduced the maximum tariff rate from 30 percent to 20 percent, bringing the number of non-zero tariffs to just three. As a result of the reform, the unweighted tariff rate declined from 15.9 percent to 14.1 percent. In addition, excise taxes on imported and domestically produced goods were unified in early 1999 and the authorities plan to remove the few remaining quantitative trade restrictions by end-July (structural benchmark). The authorities intend to reduce tariffs further in the next few years, bringing the maximum rate down to 15 percent and lowering the average rate to 10-12 percent, beginning with a reduction of the maximum rate to 18 percent in the 2000 budget. In addition, the government will remove the export bans on skins and hides, and on scrap metals, by end-July 1999 (structural benchmarks). It is committed to not introducing any new quantitative restrictions on exports or imports. Albania continues to make progress in its accession discussions with the WTO. 
34. However, progress has not all been positive. In April 1999, the authorities raised the tariff on diesel from 10 percent to 20 percent, a move aimed at providing temporary protection to the local petroleum industry whilst it restructures. ${ }^{12}$ In early 1999 , the authorities introduced automatic import licensing restrictions on fuel products to support the implementation of domestic technical standards. They continue to maintain non-automatic export licensing restrictions on wood and wood products which complement harvesting limits for forestry conservation purposes. The tariff increase will, however, be reversed by end-October 1999 as the authorities intend to expedite their restructuring plans for the petroleum industry. The authorities will also extend customs valuation based on the transactions value approach to all customs offices: owing to weak implementation capacity, much valuation in practice relies on minimum reference prices.

\section{F. External Outlook and Capacity to Repay the Fund}

35. Albania's external position is projected to deteriorate sharply in 1999. Higher import demand (in addition to imports of direct aid for refugees) arising from the effects of the Kosovo crisis and from investment and development needs, in conjunction with slower export growth than originally programmed, is expected to push the current external account deficit up from 6 percent of GDP in 1998 to 12 percent of GDP in 1999 (Table 6). At the same time, lower foreign direct investment will contribute to a weaker capital account. The strong reserve position at the end of 1998 gives the authorities some cushion to absorb the adverse impact of the Kosovo crisis. However, even allowing for a small decline in reserves, the authorities will need a considerable amount of highly concessional official financing in 1999, estimated at about US\$200 million, of which some US\$160 million is attributable directly to the Kosovo crisis.

36. Most of the required financing has been identified. Financing for the "pre-Kosovo" needs in the form of the World Bank SAC and EU balance of payments support loans had already been identified before the crisis. A subsequent pledge of an EU budgetary grant in the amount of Euro 62 million (US\$65 million), disbursement of the a new US\$30 million World Bank Public Expenditure Support Credit, a decision to enhance the SAC to US\$45 million (an additional US\$10 million would be available in 1999), and a one-year nonconcessional deferral by the Paris Club of all debt service payments takes care of about three quarters of the "Kosovo" gap. The staff expects that commitments to fill most of the residual financing needs of US\$44 million in 1999 (US\$60 million for the program year through end-March 2000) will be forthcoming at a donors' meeting on May 26. The authorities have also requested that the second annual ESAF arrangement be augmented by the equivalent of 20 percent of quota (SDR 9.7 million). Under the program, a shortfall in official external financing would trigger a reduction in external reserves up to a limit of US\$50 million. While an unprogrammed decline in reserves would be undesirable, it would not be a major risk to program objectives.

\footnotetext{
${ }^{12}$ The elimination of differential excise taxes on imported oil, at the beginning of 1999, had removed a significant element of protection for the petroleum industry.
} 
37. Financing of balance of payments needs resulting from the Kosovo crisis is expected to be provided on terms broadly consistent with agreed principles. ${ }^{13}$ Over 60 percent would be in the form of budgetary grants, 25 percent would be on IDA terms, and the remainder would be on other concessional terms. The grant element of the gap corresponding to refugee-related expenditures would be about 90 percent.

\section{On the assumption that the Kosovo crisis is resolved by end-1999, the external} position should improve to levels consistent with medium-term viability during the remainder of the three-year ESAF arrangement. With further fiscal consolidation and structural reforms contributing positively to domestic savings, the current account is expected to shrink steadily to some 6 percent of GDP by 2002. Import demand, related in particular to investment spending, will remain substantial in the medium term but exports of goods and services are expected to pick up strongly in response to improvements in productivity as reforms take hold and the security situation improves. As the regional political situation stabilizes, foreign direct investment will pick up and the need for official financing is expected to decline. Assuming foreign exchange reserve cover is maintained above $31 / 2$ months of imports of goods and services, financing gaps are on the order US\$40-50 million a year in the period 2000-2003. The debt service ratio is projected to remain below 10 percent (Table 7).

39. Albania should experience no difficulty in servicing its obligations to the Fund. The expected level of gross official reserves is comfortable, the authorities have a good record in meeting debt service payments to the Fund, and prospects for international assistance on concessional terms are good. Payments due to the Fund would peak at 23 percent of quota in 2001 .

40. The authorities are continuing their efforts to regularize relations with external creditors. They are working to complete bilateral negotiations with Russia and Italy on the rescheduling of debt in arrears subject to the July 1998 Paris Club agreement and intend to seek at least comparable treatment from non-Paris Club official bilateral and commercial creditors with outstanding claims on Albania. Negotiations on the reconciliation and rescheduling of outstanding debit balances under inoperative bilateral payments agreements are also continuing.

41. Albania also needs to improve external aid monitoring and absorption. Although an operational external debt database has been created, the development of a database on external grants has been delayed. During 1999, the government plans to complete the latter task and formalize the procedural, institutional, and legal framework for monitoring and servicing external credits and grants. Strengthening absorption capacity and removing obstacles to the disbursement of foreign aid also remain on the government's agenda. To this end, the government intends to simplify further procedures relating to the approval of foreign-financed projects and provide adequate funds for reimbursement of VAT and customs duty and for land acquisition.

${ }^{13}$ See "The Economic Consequences of the Kosovo Crisis", EBS/99/59, April 1999. 


\section{Staff Appraisal}

42. The authorities' success in restoring macroeconomic stability following the 1997 disturbances will help them to deal with the new challenges posed by the Kosovo crisis. Inflation is currently negligible, output has fully recovered its earlier losses, and reserve cover is reasonably comfortable. These positive developments stem to a large extent from the authorities' firm implementation of fiscal consolidation and prudent conduct of monetary policy. In this context, Albania has an impressive record of meeting all quantitative performance criteria under the ESAF program so far. The authorities can also point to progress in structural reforms in key areas including privatization, the financial system, agriculture, and the public sector. However, it should not be forgotten that the transition process is far from complete and Albania has a long way to go to catch up with European middle income countries.

43. The challenges posed by the Kosovo crisis are indeed formidable. The flood of refugees into Albania since the crisis erupted in late March is placing tremendous strain on the social and economic infrastructure-including the ports, which are jammed with goods to meet humanitarian needs. With administrative capacity spread thin, there is a risk of a breakdown in social order. Refugee-related costs are also a strain on the budget and balance of payments. But if sufficient support is forthcoming from abroad, and the government can maintain law and order, the crisis should not derail Albania's recovery or prove inflationary. The authorities will also need to sustain the momentum of structural reforms and efforts to improve governance if the mediumterm goal of lasting rapid growth is to be achieved.

\section{Fiscal discipline remains an important element of Albania's macroeconomic} strategy. Generous donor financing of Kosovo-related expenses should enable the government to keep within its domestic budget borrowing limits in 1999. The donors, as well as the Albanian public, have the right to expect the government to observe the highest standards of transparency in accounting for donations and expenditures connected with the Kosovo crisis.

\section{At the same time, the government will need to intensify its efforts to meet tax} collection targets in order to create sufficient room for higher spending on investment and other development and social priorities. Full implementation of the customs code, enhanced import valuation practices, and strengthened measures to combat widespread fraud and smuggling are essential to make up for a slow start at the beginning of the year. Efforts to improve tax compliance will need to continue in the medium term and be complemented by efforts to broaden the tax base through the taxation of the agricultural sector.

\section{The Bank of Albania's pragmatic handling of monetary policy since the} disturbances of 1997 has been rewarded with very low inflation. If inflation remains below the target, there is likely to be scope to cut interest rates, although the Bank of Albania has so far been rightly cautious in view of the uncertainties created by the Kosovo crisis. Fiscal consolidation also provides room within the monetary program for a sizable expansion of private credit. But such expansion will only be feasible — and moreover desirable - if bank restructuring efforts are accelerated and bank supervision practices strengthened. Better bank supervision is 
also required before the Bank of Albania can begin to more fully use indirect monetary instruments. The authorities should continue to maintain a market-determined exchange rate system, which has served Albania well in the past.

\section{For the most part, the Kosovo crisis should not affect the structural reform}

program. In particular, the authorities should aim to finalize the sale of the National Commercial Bank as soon as possible and accelerate plans for the privatization of the Savings Bank. The land registration process should be completed quickly. The authorities should implement restructuring efforts in the petroleum and mining sectors vigorously. And the management and governance problems responsible for the poor performance of the utilities should be addressed firmly and quickly.

\section{The authorities will need to be particularly vigilant and active to ensure that the} strains created by the Kosovo crisis do not weaken governance. In particular, the authorities need to continue to implement their anti-corruption program and necessary reforms in the customs administration, the judiciary, and public administration. Bringing the pyramid scheme episode to a speedy and transparent conclusion is also a priority.

\section{The authorities should continue creating an open and liberal trade and exchange}

system. In this context, the recent reduction and simplification of tariffs is to be welcomed, as are the authorities' plans to reduce tariffs further in the next few years. The authorities are urged to stick to their commitment to reverse the recent increase in tariffs on diesel: protection should not be a substitute for needed restructuring in the petroleum sector. The authorities' intention to accept the obligations of Article VIII, sections 2, 3, and 4 in the future is welcome. However, a clear timetable for the elimination of outstanding debit balances under inoperative bilateral payments agreements, which constitute restrictions subject to approval under Article VIII, is needed.

50. Albania's balance of payments position is expected to worsen in 1999. Most of the deterioration reflects the consequences of the Kosovo crisis, which has raised import demand, weakened exports somewhat, and diminished the prospects for foreign direct investment. However, generous support on largely grant terms has already been pledged by the international community. The residual financing needs are expected to be met by further grants from bilateral donors. It is hoped that the Kosovo crisis will be resolved quickly, in which case the balance of payments should recover in 2000 and the medium term-assuming domestic reforms are implemented and security concerns are overcome. Even so, Albania is likely to require additional modest amounts of official external financing on appropriate terms.

\section{Overall, the staff believes the authorities are following a strong and appropriately} ambitious program of macroeconomic stabilization and structural reform. While the refugee crisis places a strain administrative capacity, the staff believes the objectives of the program are obtainable. The authorities' track record under the first annual arrangement provides assurance that the necessary resolve to implement difficult reforms will be forthcoming. Program risks and uncertainties have of course increased, but nevertheless the staff supports the authorities' request 
for a second annual arrangement under the ESAF. In view of the increased external financing needs, and the fact that the authorities' program has not been diluted in response to the Kosovo crisis, the staff also supports the authorities' request for augmentation of the ESAF arrangement in the amount of SDR9.7 million (20 percent of quota). It is proposed that one half of the additional resources be available upon approval of the second annual arrangement and the rest upon completion of the mid-year review.

52. The staff welcomes the authorities' intentions to improve the quality of statistics, which is only minimally sufficient for program monitoring and surveillance purposes. Priority should be given to improving real sector statistics and constructing reliable national accounts data. Albania is encouraged to participate in the GDDS.

53. It is recommended that Albania remain on the standard 12-month Article IV consultation cycle. 


\section{PROPOSED DECISION}

The following draft decision is proposed for adoption by the Executive Board:

1. The Government of Albania has requested: (i) the second annual arrangement under the Enhanced Structural Adjustment Facility and (ii) an augmentation by the equivalent of SDR 9.74 million to SDR 45.04 million of the total amount of resources committed to Albania under the three-year ESAF arrangement, and for this additional amount to be made available to Albania under the second annual ESAF arrangement. The Fund approves the request.

2. Accordingly:

(a) paragraph 2(i)(a) of the three-year and first annual ESAF arrangements for Albania shall be amended by replacing the figure "SDR 35.3 million" with the figure "SDR 45.04 million".

(b) paragraph 2(i)(b) of the three-year and first annual ESAF arrangements for Albania shall be amended with respect to the sentence regarding the amount of the second annual arrangement by replacing the figure "SDR 11.77 million" with the figure "SDR 21.51 million".

3. The Fund has appraised the progress of Albania in implementing economic policies and achieving the objectives under the program supported by the first annual arrangement, and notes the updated policy framework paper set forth in EBD/99/65.

4. The Fund approves the second annual arrangement set forth in EBS/99/84. 
Table 1. Albania: Basic Indicators and Macroeconomic Framework, 1993-2002

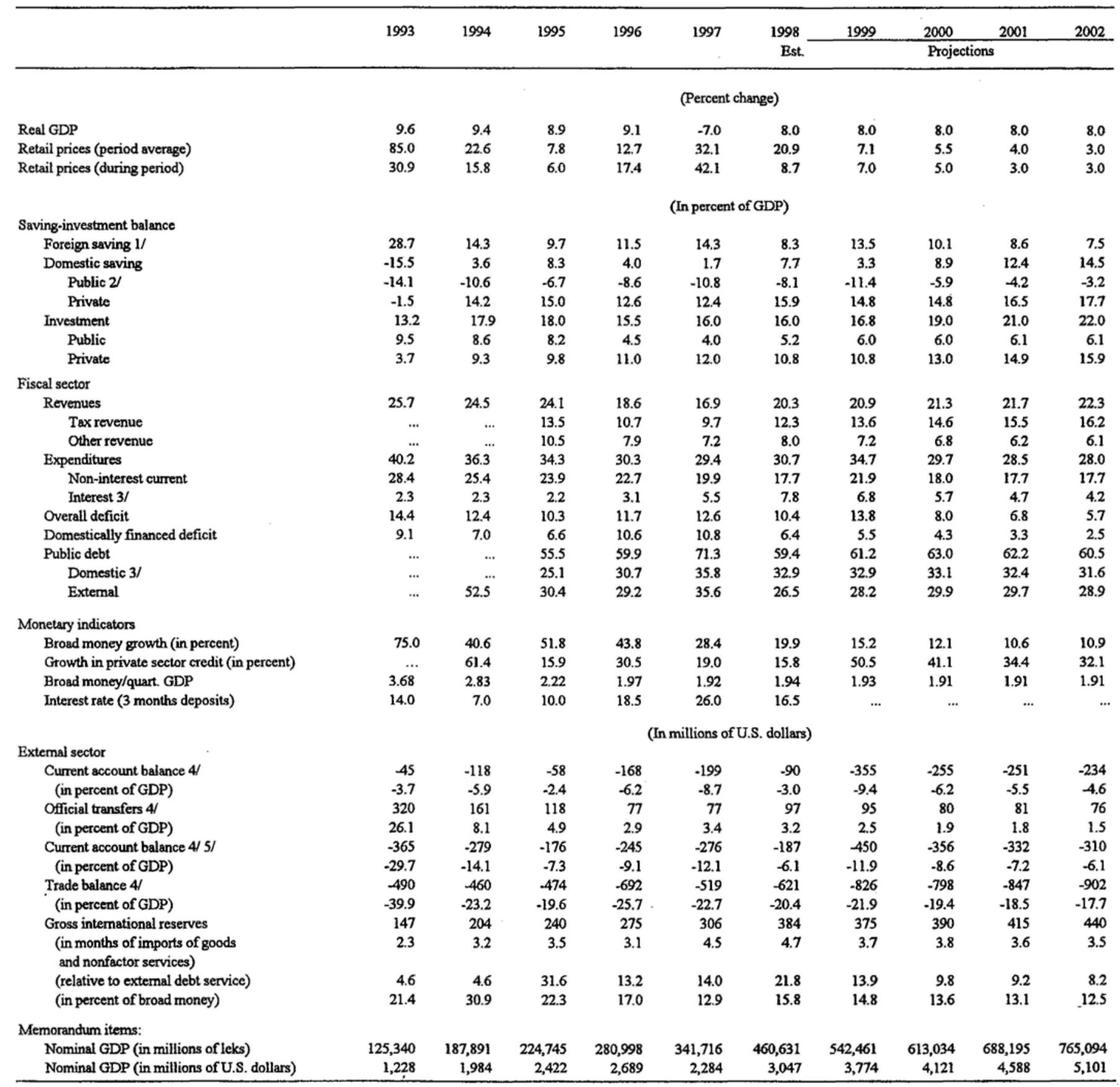

Sources: Albanian authorities; and Fund staff estimates and projections.

1/ Current account excluding net factor services and official transfers.

2/ Revenue (excluding grants) minus current expenditure.

3/ Including bonds for bank restructuring.

4/ For 1999 excluding imports of direct humanitarian aid related to the Kosovo crisis.

5/ Excluding official transfers. 
Table 2. Albania: Performance Criteria and Indicative Targets for 1998-99 1/

\begin{tabular}{|c|c|c|c|c|}
\hline $\begin{array}{l}\text { End-Dec. } \\
\text { levels } 1997\end{array}$ & $\begin{array}{c}\text { End-June } \\
1998\end{array}$ & $\begin{array}{r}\text { End-Sep. } \\
1998 \\
\end{array}$ & $\begin{array}{c}\text { End-Dec. } \\
1998\end{array}$ & $\begin{array}{c}\text { End-Mar. } \\
1999\end{array}$ \\
\hline Actual & Prog. 2/ Act. & Prog. 3/ Act. & Rev.Prog.2/ Act. & Rev.Prog.2/ Est. \\
\hline
\end{tabular}

(In billions of leks)

1. Net banking system credit to the $\begin{array}{ll}\text { government } & 147.0\end{array}$

147.0

94

23

13

$29 \quad 29$

33

33

2. Net domestic assets of the BoA 4/

$2 \quad-14$

$8-13$

$-4 \quad-6$

$-2$

$-7$

(In millions of U.S. dollars)

3. Net international reserves of the BoA 5/

151.2

$20 \quad 57$

$20 \quad 60$

60

35

43

35

37

4. Contracting or guarantecing of nonconcessional external debt with maturities $1-15$ years

Of which: $1-5$ years

5. Public and publicly-guaranteed external debt

with maturities of up to 1 year $6 /$

$\begin{array}{rr}\ldots & 10 \\ \cdots & 0\end{array}$

$\begin{array}{rr}\cdots & 20 \\ \cdots & 0\end{array}$

$\cdots$

30

$\cdots$

40

$0 \quad \cdots$

0

1/ Unless otherwise noted, all figures are expressed as cumulative changes from end-December 1997 levels. There is also a continuous performance criterion on the non-accumulation of new external arrears exclusive of arrears that are subject to rescheduling consistent with the July 1998 Paris Club terms of reference. See EBS/98/77 and EBS/99/2 for a description of the limits on performance criteria and indicative targets in the program.

2/Indicative targets.

3/ Performance criteria.

4/ Defined as reserve money minus net international reserves.

5/ These exclude holdings of nonconvertible currencies, claims on nonresident financial institutions denominated in convertible currencies; foreign currency reserves of commercial banks held at the Bank of Albania and credit and debit balances as of December 31, 1997, arising from bilateral payments agreements in clearing dollars and in rubles, and any foreign liabilities arising from debt rescheduling operations.

6/ The end-December 1997 stock of short-term debt includes already outstanding debts with maturities of 1-5 years. The figures exclude external debt in arrears which is subject to rescheduling or is in dispute. 
Table 3. Albania: Prior Actions, Structural Performance Criteria, and Structural Benchmarks Under the First Annual ESAF Arrangement

\section{Original Program}

\section{A. Prior Actions}

1. a) Full control by foreign administrators over 5 remaining pyramid scheme

Full observance companies, including through the removal of owners. (Mid-April 1998)

b) Submit to parliament legislation to establish the principles for distribution of recovered assets. (Mid-April 1998)

Full observance

2. a) Parliamentary approval of package of laws on agricultural land market. (MidApril 1998)

Full observance

b) Amend regulations to allow special registration and sale of individual agricultural holdings. (Mid-April 1998)

c) Provide adequate office space for land registries in 33 districts. (Mid-April 1998)

Full observance

3. a) Final liquidation of RCB, and in that connection, setting up of Bank Asset

Full observance Resolution Trust. (End-April 1998)

b) Agreement by Savings Bank on governance contract allowing participation with foreign bank in management. (End-April 1998)

c) Appoint foreign Chief Executive Officer for NCB. (End-April 1998)

Full observance

d) Submit to parliament revised Banking System Law. (End-April 1998)

Full observance

4. a) Approval by parliament of privatization strategy. (End-April 1998)

Full observance

b) Liquidate former ERA enterprises. (End-April 1998)

Substantial observance

Full observance

5. Reduce budgetary employment to 140,000 . (End-March 1998)

Full observance

6. Introduce excise tax on domestic and imported kerosene effective April 1, 1998. (End-March 1998)

\section{B. Structural Performance Criteria}

1. Establish ceiling on employment in budgetary institutions at 135,000 , and reduce workforce to this level. (End-September 1998)

Full observance

2. Decide on privatization of liquidation of NCB. (End-September 1998)

Full observance

\section{Structural Benchmarks}

1. Compensation from recovered assets of pyramid scheme companies only. (Throughout) 
Table 3 (continued). Albania: Prior Actions, Structural Performance Criteria, and Structural Benchmarks Under the First Annual ESAF Arrangement

Status as of endJanuary 1999

2. Full cooperation of all government agencies with administrators and auditors for all 17 pyramid scheme companies. (Throughout)

Full observance

3. No new exemptions from VAT and customs duty. (Throughout)

Full observance

4. Restrict new lending by banks with bad loans exceeding 20 percent of loan portfolio. (Throughout)

Full observance

5. Appoint international auditing firm to audit remaining $\mathbf{5}$ pyramid scheme companies. (End-April 1998)

6. Set up and make fully operational central database on employment in the budgetary sector. (Original end-September 1998, revised end-December 1998)

7. Make customs reference valuation file fully operational in all major customs clearance houses. (Original end-September 1998, revised end-March 1999)

Full observance

Substantial progress

Some progress, deadline revised end1999

8. Council of Ministers to adopt program of functional reviews covering a minimum of four ministries. (End-September 1998)

Decision adopted in January 1999

9. Council of Ministers to adopt program of functional reviews covering a minimum of four ministries. (End-September 1998)

Delay due to withdrawal of advisor

10. Complete sale of all remaining state-owned small- and medium-sized enterprises. (End-1998)

11. Bring Albanian Mobile Communications to the point of sale. (Original endSeptember 1998, revised end-April 1999)

Some progress, converted to SPC for end-September 1999

Some progress, deadline revised end1999

12. Bring Albanian Telecom to point of sale. (Original end-1998, revised end-1999)

13. Complete privatization or liquidation of NCB. (Original end-1998, revised mid-year 1999)

14. Unify excise taxes on domestic and imported goods at rates at least revenue neutral with effect from January 1, 1999. (End-1998)

15. Set up and make fully operational external debt and aid database. (Original endDecember 1998, revised debt database by end-March 1999)

Some progress

Substantial progress, Prior Action for the second Annual Arrangement Full observance

Substantial progress on debt database; deadline for aid database revised endJune 1999 
Table 3 (concluded). Albania: Prior Actions, Structural Performance Criteria, and Structural Benchmarks Under the First Annual ESAF Arrangement

\section{Measures and Deadlines}

Status as of endJanuary 1999

\section{Measures Added at Time of Review}

\section{A. Prior Actions}

1. Approval by parliament of a 1999 budget satisfactory to the IMF. (End-December 1998)

Full observance

2. Budgetary employment ceiling set at 135,000 and employment reduced to this level. (End-December 1998)

3. Approval by parliament of a law providing for the privatization of the National Commercial Bank. (Mid-January 1999)

4. Holding of auctions for at least 90 small- and medium-sized enterprises (SMEs). Sale of at least 50 SMEs. (Mid-January 1999)

5. Privatization or liquidation of two of the remaining four former Enterprise Restructuring Agency (ERA) enterprises. (Mid-January 1999)

Full observance

Full observance

Full observance

One enterprise leased for 20 years

\section{B. Structural Benchmarks}

1. Reduce budgetary employment by a further 2,000 employees to a maximum of 133,000. (End-March 1999)

Full observance

2. Reduce average tariff rate and number of tariff rates. (End-March 1999)

3. Land market

Full observance

a) Complete first registration in 1,000 cadastral zones. (End-December 1998)

b) Complete first registration in 1,150 cadastral zones. (End-March 1999)

Full observance

c) Completion of at least 2,000 sales transactions in agricultural land. (EndDecember 1998)

d) Completion of at least 2,500 sales transactions in agricultural land. (End-March 1999)

4. Privatize or liquidate final two former ERA enterprises. (End-March 1999)

Full observance

Full observance

Full observance

Liquidation expected, Prior Action for the second Annual Arrangement 
Table 4. Albania: Government Revenue and Expenditure, 1995-99

(In percent of GDP)

\begin{tabular}{|c|c|c|c|c|c|c|c|}
\hline & \multirow[t]{2}{*}{1995} & \multirow[t]{2}{*}{1996} & \multirow[t]{2}{*}{1997} & \multicolumn{2}{|c|}{1998} & \multicolumn{2}{|c|}{1999} \\
\hline & & & & Prog. & Outcome & Budget & Rev. \\
\hline Revenue and grants & 23.9 & 18.3 & 16.9 & 21.7 & 20.3 & 21.2 & 20.9 \\
\hline Tax revenue & 13.5 & 10.7 & 9.7 & 14.1 & 12.3 & 13.9 & 13.6 \\
\hline Tumover tax/VAT & 2.5 & 3.2 & 4.6 & 7.4 & 6.2 & 6.7 & 6.5 \\
\hline Excise taxes & 5.1 & 1.8 & 0.6 & 1.3 & 1.1 & 1.3 & 1.3 \\
\hline Main direct taxes & 2.1 & 2.2 & 1.2 & 1.4 & 1.5 & 1.9 & 1.9 \\
\hline Profit tax & 1.1 & 1.2 & 0.7 & 0.8 & 0.9 & 1.0 & 1.0 \\
\hline Small business tax & 0.4 & 0.3 & 0.1 & 0.2 & 0.2 & 0.2 & 0.2 \\
\hline Personal income tax & 0.3 & 0.2 & 0.2 & 0.2 & 0.3 & 0.5 & 0.5 \\
\hline Property and local taxes & 0.4 & 0.5 & 0.2 & 0.3 & 0.2 & 0.2 & 0.2 \\
\hline Customs duties & 2.8 & 2.7 & 2.6 & 3.3 & 2.7 & 2.8 & 2.7 \\
\hline Other taxes & 1.0 & 0.8 & 0.6 & 0.7 & 0.7 & 1.2 & 1.2 \\
\hline Social insurance contributions & 4.1 & 4.5 & 3.8 & 3.2 & 3.4 & 3.4 & 3.4 \\
\hline Nontax revenue & 6.2 & 3.0 & 3.3 & 4.4 & 4.5 & 3.9 & 3.9 \\
\hline Profit transfer from the $\mathrm{BoA}$ & 2.6 & 1.4 & 2.4 & 3.5 & 3.6 & 2.9 & 2.9 \\
\hline Income of budgetary institutions & 1.8 & 1.0 & 0.5 & 0.6 & 0.7 & 0.7 & 0.7 \\
\hline Other & 1.8 & 0.7 & 0.4 & 0.3 & 0.3 & 0.3 & 0.3 \\
\hline Primary expenditure $1 /$ & 32.1 & 27.3 & 24.0 & 27.7 & 22.9 & 24.1 & 27.9 \\
\hline Current noninterest expenditure 1/ & 23.6 & 22.7 & 19.9 & 19.4 & 17.7 & 18.1 & 18.1 \\
\hline Personnel & 8.2 & 8.2 & 7.5 & 6.2 & 6.2 & 5.8 & 5.8 \\
\hline Operations and maintenance & 5.4 & 4.4 & 4.0 & 4.0 & 4.0 & 4.1 & 4.1 \\
\hline Direct subsidies & 0.6 & 0.4 & 0.5 & 0.3 & 0.5 & 0.3 & 0.3 \\
\hline Social insurance & 7.7 & 8.0 & 6.5 & 6.1 & 5.6 & 5.7 & 5.7 \\
\hline Social assistance & 1.6 & 1.4 & 1.3 & 1.6 & 1.3 & 1.2 & 1.2 \\
\hline Other current expenditures & 0.1 & 0.4 & 0.2 & 1.2 & 0.0 & 1.1 & 1.1 \\
\hline Investment $1 /$ & 8.5 & 4.5 & 4.0 & 8.3 & 5.2 & 6.0 & 6.0 \\
\hline Domestically financed & 5.0 & 3.2 & 1.9 & 2.4 & 2.3 & 2.4 & 2.4 \\
\hline Foreign financed & 3.5 & 1.3 & 2.1 & 5.8 & 2.9 & 3.6 & 3.6 \\
\hline Refugee related expenditures $2 /$ & $\cdots$ & $\cdots$ & $\cdots$ & $\cdots$ & $\cdots$ & $\cdots$ & 3.8 \\
\hline Primary balance $1 /$ & -8.2 & -9.0 & -7.1 & -6.0 & -2.6 & -2.9 & -7.0 \\
\hline Interest expenditure & 2.2 & 3.1 & 5.5 & 7.9 & 7.8 & 6.8 & 6.8 \\
\hline Balance for financing (cash) & 10.4 & 12.1 & 12.6 & 13.9 & 10.4 & 9.8 & 13.8 \\
\hline \multicolumn{8}{|l|}{ Financing: } \\
\hline Domestic financing (cash) & 6.6 & 11.0 & 10.8 & 6.6 & 6.4 & 5.7 & 5.5 \\
\hline Privatization revenues & 0.1 & 0.2 & 0.3 & 0.3 & 0.0 & 0.6 & 0.6 \\
\hline Other $3 /$ & 6.5 & 10.8 & 10.5 & 6.3 & 6.4 & 5.1 & 4.9 \\
\hline Foreign financing & 3.8 & 1.1 & 1.8 & 7.3 & 4.0 & 4.1 & 8.3 \\
\hline Development finance & 3.5 & 1.3 & 2.1 & 5.8 & 2.9 & 3.6 & 3.6 \\
\hline External budget support & 0.3 & 0.0 & 0.0 & 1.8 & 1.4 & 1.0 & 5.1 \\
\hline Minus: Principal repayments (foreign) & 0.0 & 0.3 & 0.3 & 0.3 & 0.3 & 0.5 & 0.3 \\
\hline Change in arrears (increase $=+$ ) & -0.1 & 0.0 & 0.0 & 0.0 & 0.0 & 0.0 & 0.0 \\
\hline Overall deficit (including arrears) & 10.3 & 12.1 & 12.6 & 13.9 & 10.4 & 9.8 & 13.8 \\
\hline \multicolumn{8}{|l|}{ Memorandum items: } \\
\hline Domestic financing (billion leks) $4 /$ & 14.6 & 30.8 & 36.9 & 30.4 & 29.7 & 30.9 & 29.8 \\
\hline Revenue minus domestic expenditure & -6.9 & -10.7 & -10.5 & -8.1 & -7.5 & -6.2 & -10.2 \\
\hline Bonds issued for bank restructuring & 0.0 & 0.0 & 0.0 & 0.9 & 0.0 & 2.9 & 1.3 \\
\hline Augmented balance $5 /$ & -10.3 & -12.1 & -12.6 & -14.8 & -10.4 & -12.7 & -15.1 \\
\hline Expenditures by function $6 /$ & & & & & & & - \\
\hline Health & 2.4 & 2.1 & 1.8 & 1.9 & 1.5 & 1.9 & 1.9 \\
\hline Education & 3.8 & 3.4 & 3.3 & 3.0 & 2.8 & 2.5 & 2.5 \\
\hline Public order & 2.3 & 2.0 & 2.5 & 0.8 & 1.8 & 0.7 & 0.7 \\
\hline Defense & 2.2 & 1.7 & 1.3 & 1.1 & 1.1 & 1.0 & 1.0 \\
\hline Domestic debt (percent of GDP, end-year) & 25.1 & 30.9 & 35.9 & 33.0 & 33.0 & 33.2 & 33.0 \\
\hline Budgetary employment (year average, thousands) & 161.3 & 151.0 & 151.0 & 141.0 & 141.0 & 131.5 & 131.5 \\
\hline \multicolumn{8}{|l|}{ Wages in budgetary institutions (end-1995 $=100$ ) } \\
\hline Average nominal wage (period end) & 100.0 & 120.0 & 120.0 & 151.3 & 151.3 & 177.5 & 177.5 \\
\hline Average real wage (period end) & 100.0 & 102.2 & 71.9 & 82.4 & 82.4 & 90.4 & 90.4 \\
\hline GDP (billion leks) & 224.7 & 281.0 & 341.7 & 459.3 & 460.6 & 542.5 & 542.5 \\
\hline
\end{tabular}

Sources: Albanian authorities; and Fund staff estimates and projections.

1/ Excluding Kosovo related expenditures.

2/ Costs related to the influx of refugees from Kosovo after March 1999.

3/ Almost all of this is financed by the banking system. In addition, a very small amount of treasury bills is held by the state insurance company (INSIG) and the private sector.

4/ Including arrears and privatization receipts.

5/ Overall balance including bonds issued for bank restructuring.

6/ The expenditure figures based on the functional classification are highly provisional. The Albanian authorities have only recently started work on the functional classification, and statistics experts from the Fund will provide assistance to the authorities in this area in early 1999. Estimates for 1998 reflect the outcomes for the first three quarters of the year only. 
Table 5. Albania: Monetary Aggregates, 1997-2002

(In billions of leks, end period)

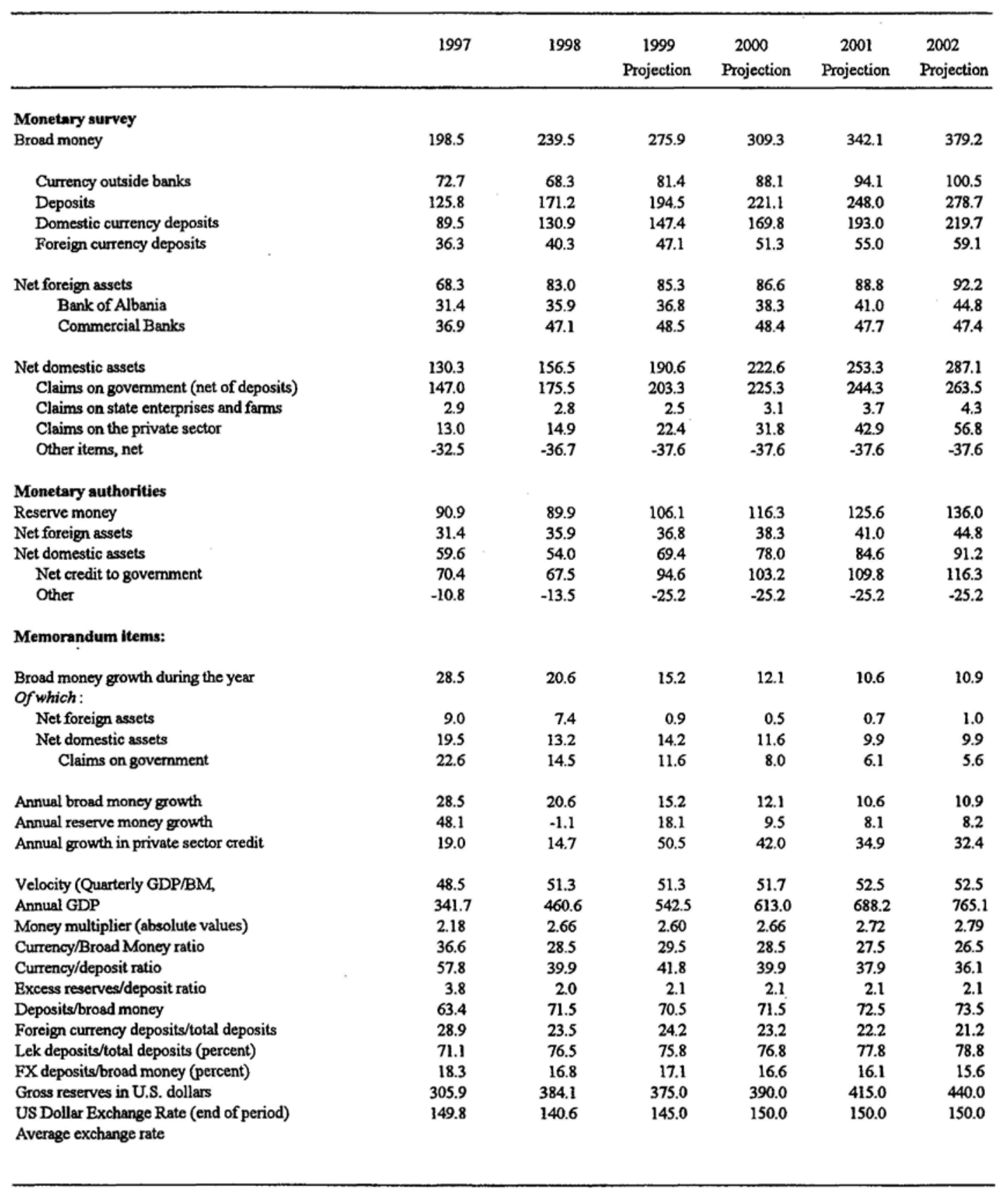

Sources: Bank of Albania; and staff estimates. 
Table 7. Albania: Projected Payments to the Fund as at April 30, 1999 (In millions of SDRs)

\begin{tabular}{|c|c|c|c|c|c|c|c|c|c|c|c|c|c|}
\hline & Overdue & 1999 & 2000 & 2001 & 2002 & 2003 & 2004 & 2005 & 2006 & 2007 & 2008 & Beyond & Total \\
\hline \multicolumn{14}{|l|}{ Obligations from existing drawings } \\
\hline \multicolumn{14}{|l|}{ 1. Principal } \\
\hline a. Repurchases & 0.0 & 0.0 & 0.0 & 4.4 & 4.4 & 0.0 & 0.0 & 0.0 & 0.0 & 0.0 & 0.0 & 0.0 & 8.8 \\
\hline b. ESAF/SAF repayments & 0.0 & 1.7 & 5.5 & 6.2 & 6.2 & 6.8 & 5.4 & 3.1 & 2.4 & 2.4 & 1.8 & 0.6 & 42.0 \\
\hline \multicolumn{14}{|l|}{ 2. Charges and interest $1 /$} \\
\hline a. on Fund credit & 0.0 & 0.5 & 0.5 & 0.4 & 0.2 & 0.1 & 0.1 & 0.0 & 0.0 & 0.0 & 0.0 & 0.0 & 1.9 \\
\hline b. on use of SDRs & 0.0 & -0.4 & 0.0 & 0.0 & 0.0 & 0.0 & 0.0 & 0.0 & 0.0 & 0.0 & 0.0 & 0.0 & -0.4 \\
\hline Total obligations & 0 & 1.8 & 6 & 11.1 & 10.9 & 6.9 & 5.5 & 3.1 & 2.4 & 24 & 1.8 & 0.6 & 52.3 \\
\hline (Percent of quots) & 0 & 3.6 & 12.4 & 22.7 & 22.3 & 14.2 & 11.3 & 6.4 & 4.9 & 49 & 3.6 & 1.2 & 107.5 \\
\hline \multicolumn{14}{|c|}{ Obligations from prospective drawings $2 /$} \\
\hline \multicolumn{14}{|l|}{ 1. Principal } \\
\hline a. Repurchases & 0 & 0 & 0 & 0 & 0 & 0 & 0 & 0 & 0 & 0 & 0 & 0 & \\
\hline b. ESAF/SAF Repsyments & 0 & 0 & 0 & 0 & 0 & 0.5 & 1.9 & 3.8 & 4.8 & 4.8 & 8.1 & 23.9 & \\
\hline \multicolumn{14}{|l|}{ 2. Charges and interest $1 /$} \\
\hline A. on Fund credit & 0 & 0.1 & 0.1 & 0.1 & 0.1 & 0.1 & 0.1 & 0.1 & 0.1 & 0.1 & 0 & 0.9 & \\
\hline b. on use of SDRs & 0 & 0 & 0 & 0 & 0 & 0 & 0 & $\mathbf{0}$ & 0 & $\mathbf{0}$ & 0 & 0 & \\
\hline Total obligations $2 /$ & 0 & 0.1 & 0.1 & 0.1 & 0.1 & 0.6 & 2 & 3.9 & 4.9 & 4.8 & 8.1 & 24.8 & \\
\hline (percent of quota) & 0 & 0.1 & 0.2 & 0.2 & 0.2 & 1.2 & 4.2 & 8.1 & 10 & 9.9 & 16.7 & 50.9 & \\
\hline \multicolumn{14}{|c|}{ Cumulative (existing and prospective) 2/ } \\
\hline \multicolumn{14}{|c|}{ 1. Prineipal } \\
\hline s. Repurchases & 0 & 0 & 4.4 & 4.4 & 0 & 0 & 0 & 0 & 0 & 0 & 0 & 8.8 & \\
\hline b. ESAF/SAF Repayments & 1.7 & 5.5 & .6 .2 & 6.2 & 6.8 & 5.9 & 5 & 6.2 & 7.1 & 6.5 & 8.7 & 65.8 & \\
\hline 2. Charges and interest $1 /$ & & & & & $\cdot$ & & & & - & & & & \\
\hline a. on Fund credit & 0.5 & 0.6 & 0.5 & 0.4 & 0.2 & 0.2 & 0.2 & 0.1 & 0.1 & 0.1 & 0 & 2.8 & \\
\hline b. on use of SDRs & -0.4 & 0 & 0 & 0 & 0 & 0 & 0 & 0 & 0 & 0 & 0 & -0.4 & \\
\hline Total obligations $2 /$ & 1.8 & 6.1 & 11.2 & 11 & 7 & 6.1 & 5.1 & 6.3 & 7.2 & 6.6 & 8.7 & 77.1 & \\
\hline (percent of quots) & 3.7 & 125 & 22.9 & 22.5 & 14.4 & 12.5 & 10.6 & 13 & 14.8 & 13.6 & 17.9 & 158.4 & \\
\hline $\begin{array}{l}\text { Outstanding Fund credit } 2 / 3 / \text { } \\
\text { (In millions of SDRs) }\end{array}$ & 0.0 & 549 & 61.2 & $\$ 6.4$ & 45.9 & 39.1 & 33.1 & 27.7 & 21.2 & 14.1 & 14.1 & $\cdots$ & $\ldots$ \\
\hline \multicolumn{14}{|l|}{ In percent of: } \\
\hline Exports of goods & $\ldots$ & 29.1 & 26.6 & 21.3 & 15.7 & 12.0 & $\cdots$ & $\cdots$ & $\cdots$ & $\cdots$ & $\cdots$ & $\ldots$ & $\cdots$ \\
\hline Extemal public debt & $\cdots$ & 7.7 & 7.3 & 5.3 & 4.0 & 3.1 & ... & $\ldots$ & $\ldots$ & $\cdots$ & $\ldots$ & $\cdots$ & $\cdots$ \\
\hline Gross official reserves & $\ldots$ & 19.5 & 20.7 & 18.0 & 13.8 & 11.1 & $\cdots$ & $\cdots$ & $\cdots$ & $\cdots$ & $\cdots$ & $\cdots$ & $\cdots$ \\
\hline GDP & $\ldots$ & 2.0 & 2.0 & 1.6 & 1.2 & 0.9 & $\cdots$ & $\cdots$ & $\cdots$ & $\cdots$ & $\cdots$ & $\cdots$ & $\cdots$ \\
\hline Quots & $\cdots$ & 155.5 & 173.2 & 159.9 & 130.1 & 110.8 & $\ldots$ & $\ldots$ & $\ldots$ & $\ldots$ & $\ldots$ & $\cdots$ & $\cdots$ \\
\hline $\begin{array}{l}\text { Repurchases and charges due } 2 / 3 / \\
\text { (In millions of SDRs) }\end{array}$ & 0.0 & 6.1 & 11.2 & 11.0 & 7.0 & 6.1 & 6.2 & 5.6 & 6.6 & 7.2 & 7.2 & 14.2 & $\cdots$ \\
\hline \multicolumn{14}{|l|}{ In percent of: } \\
\hline Exports of goods & $\ldots$ & 3.2 & 4.9 & 4.2 & 2.4 & 1.9 & $\cdots$ & $\cdots$ & $\cdots$ & $\cdots$ & $\ldots$ & $\ldots$ & $\cdots$ \\
\hline Extemal public debt & $\ldots$ & 0.9 & 1.3 & 1.0 & 0.6 & 0.5 & $\ldots$ & $\cdots$ & $\cdots$ & $\cdots$ & $\cdots$ & $\cdots$ & $\ldots$ \\
\hline Gross official reserves & $\ldots$ & 2.2 & 3.8 & 3.5 & 2.1 & 1.7 & $\cdots$ & $\cdots$ & $\cdots$ & $\ldots$ & $\ldots$ & $\cdots$ & $\cdots$ \\
\hline GDP & $\ldots$ & 0.2 & 0.4 & 0.3 & 0.2 & 0.1 & $\ldots$ & $\ldots$ & $\cdots$ & $\ldots$ & $\cdots$ & $\ldots$ & $\ldots$ \\
\hline Quota & $\ldots$ & 12.5 & 22.9 & 22.5 & 14.4 & 12.5 & $\cdots$ & $\cdots$ & $\ldots$ & $\ldots$ & $\cdots$ & $\cdots$ & $\cdots$ \\
\hline
\end{tabular}

1/Projections are based on current rates of charge, including burden-sharing charges where spplicable, for purchases in the GRA, and on current interest rates for SFA, ESAF, and Trust Fund. The current SDR interest rate is assumed for net use of SDRs.

2/ This assumes that the BSAF arrangement is augmented by SDR 9.7 million and fully disbursed during 1999-2001.

3/ Under the assumptions of the modium-term balance of payments projections. 


\section{Albania: Fund Relations \\ As of April 30, 1999}

I.

A. Membership Status: Joined: 10/15/1991; Article XIV

II. General Resources Account:

Quota

Fund Holdings of Currency

Reserve position in Fund

III. SDR Department:

Holdings

IV. Outstanding Purchases and Loans:

ESAF arrangements

First Credit Tranche $\underline{\text { SDR Million }}$

48.70

54.18

3.36

$\underline{\text { SDR Million }}$

45.39

SDR Million

41.98

8.83
\%Quota

100.0

111.2

6.9

\%Allocation

N/A

\%Quota

86.2

18.1

V. Financial Arrangements:

$\begin{array}{lcccc}\text { Type } & \begin{array}{c}\text { Approval } \\ \text { Date }\end{array} & \begin{array}{c}\text { Expiration } \\ \text { Date }\end{array} & \begin{array}{c}\text { Amount Approved } \\ \text { (SDR Million) }\end{array} & \begin{array}{c}\text { Amount Drawn } \\ \text { (SDR Million) }\end{array} \\ \text { ESAF } & 05 / 13 / 1998 & 05 / 12 / 2001 & 35.30 & 11.77 \\ \text { ESAF } & 07 / 14 / 1993 & 07 / 13 / 1996 & 42.36 & 31.06 \\ \text { Stand-by } & 08 / 26 / 1992 & 07 / 14 / 1993 & 20.00 & 13.13\end{array}$

VI. Projected Obligations to Fund:(SDR Million; based on existing use of resources and present holdings of SDRs):

Overdue

$\underline{04 / 30 / 1999}$

Principal

Charges/Interest

Total

Total

\section{Exchange Rate Arrangement}

On July 1, 1992 the Albanian authorities announced the removal of virtually all exchange and quantitative trade restrictions, unified the exchange markets, and adopted a floating exchange rate system (an independent float). The unified exchange rate stood at 145.20 lek per U.S. dollar on April 30, 1999.

\section{Resident Representative}

A Fund resident representative has been posted in Tirana since April 1993;

Mr. Volker Treichel has held this position since January 1999. 


\section{Technical Assistance}

The Fund, other multilateral organizations and donors have provided extensive assistance for institutional development in Albania. The Fund alone has sent over 75 technical assistance missions to Albania since 1991. However, further institutional development is required in virtually every sector. 


\section{Albania: Relations with the World Bank Group}

\section{Background}

1. Albania joined the World Bank Group in October 1991. Since then, the Bank has been actively involved in the design and implementation of Albania's reform program through its policy advice, lending operations, and technical assistance in various sectors. Beginning with the Critical Imports Project in 1992, the Bank to date has approved a total of 30 operations amounting to US $\$ 395.75$ million in credits, of which 7 are completed now. Under the current Bank portfolio (US\$283.25 million), 11 percent of the credits support adjustment, 8 percent agriculture, 56 percent infrastructure, 14 percent social sectors, and 11 percent technical assistance.

\section{Current and medium-term initiatives}

2. The Bank has been actively supporting Albania's economic recovery efforts after the 1997 crisis. The Rehabilitation Credit, approved by the Bank Board in December 1997, provided support for priority structural measures (resolution of the pyramid schemes and reform of the banking sector), and for alleviating the increased poverty and unemployment generated by the crisis. The Rehabilitation Credit was approved in parallel with the Recovery Program TA Project which is financing the implementation of the policy measures supported by the Rehabilitation Credit. In February 1998, the Bank Board approved the Private Industry Recovery Project, which provides political risk cover for commercial financing of productive activities. An Urban Land Management Project and Durres Port Project were also approved in 1998, and support priority infrastructure development. In addition, the Health Recovery and Development Project provides support in a priority area of the social sectors after the 1997 crisis.

3. The Bank's Country Assistance Strategy (CAS) for Albania was approved in 1998 and covers the period of 1998-2001. The CAS focuses on 3 strategic priorities: (i) Governance and institution building to help to establish an accountable, transparent and efficient state. The Bank will address these issues through a judicial and public administration reform project. (ii) Private sector development (including maintenance of macroeconomic stability, financial sector and enterprise reforms, and infrastructure improvement) and (iii) Human development and poverty alleviation. The Community Works Project was approved in January 1999, to assist rural communities with infrastructure and social infrastructure development.

4. In response to the Kosovo crisis and the huge influx of refugees, the Bank has put more immediate emphasis on support to the social sectors, especially health and education, and on emergency interventions in infrastructure like water supply, sewerage and solid waste disposal. The Bank's activities are mainly aimed at long-term development objectives rather than short-term relief, but include cooperation with other donors, especially nongovernmental organizations, in areas of relief and humanitarian assistance. The recently approved Public Expenditure Support Credit of US\$30 million is an example for efforts to 
strengthen Albania's budget and the government's ability to coordinate and direct international aid in an efficient way. Furthermore, in June 1999 the Irrigation II Project, a Structural Adjustment Credit and supplementary financing for the ongoing Community Works Project will be discussed by the Board.

\section{STATUS OF BANK GROUP OPERATIONS IN ALBANIA}

\section{A. Statement of IDA Credits \\ (As of May 1, 1999)}

\begin{tabular}{|c|c|c|}
\hline $\begin{array}{l}\text { Credit } \\
\text { No. }\end{array}$ & $\begin{array}{c}\text { Fiscal } \\
\text { Year }\end{array}$ & Borrower \\
\hline \multicolumn{3}{|c|}{ Undisbursed ${ }^{2}$} \\
\hline 2499 & 1993 & Republic of Albania \\
\hline 2534 & 1994 & Republic of Albania \\
\hline 2543 & 1994 & Republic of Albania \\
\hline 2544 & 1994 & Republic of Albania \\
\hline 2610 & 1994 & Republic of Albania \\
\hline 2633 & 1994 & Republic of Albania \\
\hline 2646 & 1995 & Republic of Albania \\
\hline 2652 & 1995 & Republic of Albania \\
\hline 2659 & 1995 & Republic of Albania \\
\hline 2680 & 1995 & Republic of Albania \\
\hline 2732 & 1995 & Republic of Albania \\
\hline 2770 & 1996 & Republic of Albania \\
\hline 2795 & 1996 & Republic of Albania \\
\hline 2826 & 1996 & Republic of Albania \\
\hline 2846 & 1996 & Republic of Albania \\
\hline 2888 & 1996 & Republic of Albania \\
\hline 3016 & 1998 & Albania \\
\hline 3038 & 1998 & Ministry of Finance \\
\hline 3066 & 1998 & Min. of Constructio \\
\hline 3067 & 1998 & Gov. of Albania \\
\hline 3068 & 1998 & Gov. of Albania \\
\hline 3164 & 1999 & Gov, of Albania \\
\hline
\end{tabular}

\begin{tabular}{l}
\multicolumn{1}{c}{ Project } \\
\hline Transport \\
Housing \\
Social Safety Net \\
Labor Market Development \\
Durres Water Supply \\
School Rehab. and Capacity Building \\
Technical Assistance for TTax Modernization \\
Irigation Rehabilitation \\
Health Services Rehabilitation \\
Rural Development \\
Rural Roads \\
Urban Works and Microenterprise \\
Agroprocessing Development \\
Power Transmission and Distribution \\
Forestry \\
National Roads \\
Recovery Program for Technical Assistance \\
Private Industry Recovery \\
Land Development \\
Health Recovery and Development \\
Durres Port \\
Community Works*
\end{tabular}

Total

"Not yet effective

Total Disbursed

Of Which: Repaid Total Now Held by IDA

Total Amount Sold Of Which: Repaid

Total Undisbursed

\begin{tabular}{r} 
Active Projects \\
\hline 117.25 \\
0.00 \\
253.25 \\
0.00 \\
0.00 \\
131.03
\end{tabular}

\begin{tabular}{c} 
Closed Projects \\
\hline 113.12 \\
0.00 \\
112.47 \\
0.00 \\
0.00 \\
70
\end{tabular}

Total

230.37

0.00

365.72

0.00

0.00

131.73

\begin{tabular}{rr}
\multicolumn{2}{c}{ US\$ Million } \\
(Less Cancellations) \\
Credit \\
\hline & \\
18.00 & .65 \\
15.00 & .91 \\
5.50 & .46 \\
5.40 & .67 \\
11.60 & 3.83 \\
9.60 & 1.10 \\
4.00 & 1.71 \\
10.00 & .16 \\
12.40 & 7.17 \\
6.00 & .63 \\
15.00 & 2.77 \\
4.00 & .43 \\
6.00 & 2.05 \\
29.50 & 19.50 \\
8.00 & 5.15 \\
25.00 & 19.57 \\
5.00 & 3.75 \\
10.25 & 8.22 \\
10.00 & 9.68 \\
17.00 & 16.71 \\
17.00 & 17.09 \\
9.00 & 8.82 \\
& \\
253.25 & 131.03
\end{tabular}

\footnotetext{
${ }^{1}$ The status of these projects is described in a separate report on all Bank/IDA financed projects in execution, which is updated twice yearly and circulated to the Executive Directors on April 30 and October 31 ,
}

'The undisbursed amounts are the USS millions equivalent of the amount in SDR at the exchange rate in effect on September $30,1998$. 


\section{B. Statement of IFC Investments}

(As of March 31, 1999)

There are three IFC operations in Albania: (i) a US\$1.2 million loan to SEF Eurotech, a cement bagging company near the port of Durres; (ii) the Patos Marinza Project for enhanced oil recovery, consisting of a US\$29 million equity commitment (of which US\$5 million has been undertaken) and a US $\$ 30$ million loan pending commitment; and (iii) the US\$1.5 million Euromerchant Albania Venture Capital Fund project. 


\title{
Albania: Technical Assistance
}

1. Technical assistance has been instrumental in Albania's institutional development since the start of the transition process. In virtually all public areas, multilateral and bilateral donors have provided extensive support and the authorities have generally achieved a good track record of implementing the recommendations. The Fund alone has fielded more than 75 technical assistance missions covering the following areas:

- A recent multisector mission by the Fund's Statistics Department found good implementation of past advice. This advice focused on price statistics, monetary accounts, the balance of payments, and the fiscal sector, and had enabled regular transmissions of data for publication in all but the last of these areas to be established. A resident technical advisor arriving in June 1999 will help develop national account statistics. Producer price statistics and government finance statistics are expected to meet international standards by end-1999 with further input from STA.

\begin{abstract}
Assistance from the Monetary and Exchange Affairs Department focused on establishing a modern central bank during the early stages of transition. The technical assistance was complemented by significant input from the Legal Department. Albania now has a modern and independent central bank with sole authority over monetary policy; a resident advisor has been assisting the central bank in the design of monetary policy. Technical assistance is now being focused on the organization of a stable market-oriented banking sector, the implementation of indirect monetary policy instruments, including bank regulation and supervision.
\end{abstract}

- The Fiscal Affairs Department's technical assistance has addressed revenue generation and public expenditure management in parallel. Having concentrated on establishing a viable modern fiscal framework early on, FAD has provided detailed advice on direct and indirect taxation, including trade taxation and tax administration, over the past years. The design of tax legislation has also benefited from input from the Legal Department. Continuing efforts to improve expenditure management, in particular budget preparation and execution, will be supported by a long-term expert arriving in June.

2. The World Bank, the European Union, and other bilateral donors continue to provide extensive assistance in many areas. In particular, the EU Customs Administration Mission is helping in the implementation of the new customs code and in the modernization of the customs administration in general. Consistent with the broad content of the Structural Assistance Credit, the World Bank is providing substantial assistance in the reform of the public administration, the judiciary, the financial sector, the education system, the social safety net, the agricultural land market, public expenditures, privatization, and enterprise restructuring. Bilateral donors are complementing much of this work with guidance from the World Bank and the Fund. Their assistance is not confined to economic issues and covers a wide array of areas, including public security and law enforcement, which are indispensable for economic and social development. 


\section{Albania: Statistical Issues}

1. Albania has made significant progress in improving its statistical database with extensive technical assistance, including from the Fund. However, much still remains to be done. In particular, a system of national accounts needs to be set up, external debt and aid monitoring needs to be strengthened, and improvements are needed in the balance of payments statistics. STA has chosen Albania as a focus country for enhanced technical assistance, has appointed a country project manager, and has conducted a multisector mission in February 1999. The multisector mission secured agreement of the authorities on an action plan for each of the major statistical areas, identifying concrete steps and a timetable for improving Albania's macroeconomic statistics. In spite of uncertainties arising from the Kosovo crisis, the authorities have thus far been on track in implementing the action plan. Albania has been selected as a GDDS pilot country for Eastern Europe in the preparation of descriptions of current statistical data compilation and dissemination practices and plans for data improvements.

\section{Real sector}

2. STA has provided considerable technical assistance to Albania on price statistics. The consumer price index (CPI) constructed by the statistical institute (INSTAT) meets international standards. It is reported regularly for publication in the Albania page in the International Financial Statistics (IFS). As regards the producer price index (PPI) there has been good progress on the recommendations of the 1998 missions, although the goal of initial publication in January 1999 was not met. Prices have been collected, and compilation of preliminary indices has been completed. A final follow-up mission from STA on the PPI to review and validate the data prior to publication is envisaged for August 1999.

3. In the absence of official national income and product accounts since 1990, Fund staff have relied on their own estimates during consultations with the authorities. These estimates are based on very partial data on (gross) agricultural output, activity in state industrial production, and extremely limited information on private sector activity. The STA multisector mission has worked with the INSTAT in developing a work program for the compilation of national accounts statistics. To assist INSTAT in implementing that work program, the Fund will provide a resident national accounts advisor for a period of 5-6 months beginning in July 1999.

4. The trade statistics missions in 1992 and 1993 improved data compilation up to international standards, but trade values, volumes, and prices are not reported for publication in IFS. After the 1997 crisis, the Customs has resumed collecting and processing data on the value and quantity of imports (c.i.f.) and exports (f.o.b.) at all entry points. Plans for improving the quality of trade statistics include the forthcoming introduction of the Automated System of Customs Data (ASYCUDA) with EU assistance. 


\section{Government finance}

5. The Ministry of Finance (MoF) has made considerable progress in improving the quality and timeliness of data compilation and dissemination. The classification issues identified during the 1995 GFS mission were resolved and a computerized routine for compiling monthly GFS-based reports was instituted. Considerable improvement in collection of data on disbursement of foreign loans and grants has been achieved under the technical assistance provided by UNCTAD. A foreign debt database has been established and is nearly operational, requiring only auditing for final implementation. Monthly fiscal tables are now published in the MoF's Fiscal Statistics of Government, a publication introduced in 1998. Annual GFS accounts for 1996 and 1997 were completed and final accounts for 1998 are expected by mid-July 1999 . The authorities have resumed the reporting of data to STA for publication.

\section{Monetary accounts}

6. Following a money and banking statistics mission in January-February 1996, the quality of monetary statistics improved and the regular reporting of data to STA resumed. This led to the introduction of a country page for Albania in the September 1996 issue of IFS. However, in the first half of 1997, security problems (including destruction of bank records and damages to bank branches) and transfer of branches among state-owned commercial banks resulted in slippages in the timeliness and quality of data. Data for the BoA and banking institutions are now being reported and published in IFS with normal lags.

7. A new plan of accounts for the commercial banks has been elaborated with technical assistance from the European Union, and is being introduced in the commercial banks. The multisector mission developed a revised framework for compiling monetary statistics based on the new plan of accounts. A follow-up technical assistance mission is planned in September 1999 to review the implementation of the action plan for further improving the monetary statistics, such as the compilation of data based on the revised framework and expansion of the coverage to include the savings and loan associations.

\section{Balance of payments}

8. The 1994 balance of payments statistics mission found the data compiled by the BoA to be methodologically sound, although some of the estimates needed to be refined. Since then, the BoA has established data compilation procedures based on the classification system of the fifth edition of the IMF's Balance of Payments Mamual. The BoA reports quarterly data to STA on a regular and timely basis. However, the multisector mission identified weaknesses in coverage and classification mainly as a result of inadequate data sources. The scope of surveys is limited as the private sector, including direct investment enterprises, is not covered. Estimation procedures for smuggling, freight and insurance on imports, and inflows of workers' remittances remained unchanged for a long period. To address these weaknesses, the mission recommended strengthening existing data sources, conducting new surveys, and improving estimation methods. 


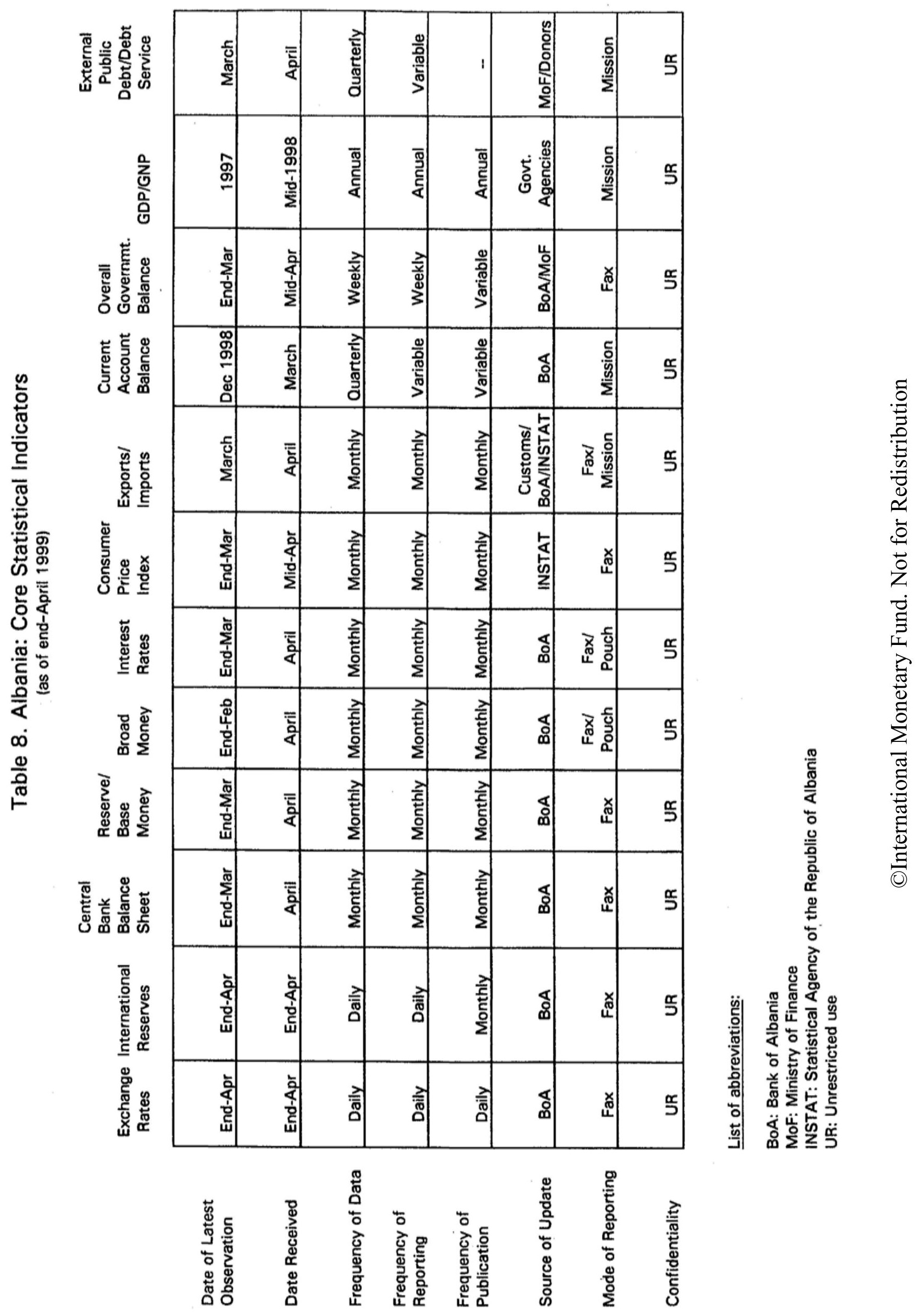




\section{Albania: Second Annual Arrangement Under the Enhanced Structural Adjustment Facility}

Attached hereto is a letter (the "Letter") with an annexed memorandum of economic and financial policies (the "Memorandum") dated May 22, 1999 from the Prime Minister, the Minister of Finance of Albania as well as the Governor of the Bank of Albania requesting from the International Monetary Fund as Trustee of the Enhanced Structural Adjustment Facility Trust (the "Fund") the second annual arrangement under the Enhanced Structural Adjustment Facility, and setting forth the objectives and policies of the program to be supported by that arrangement.

To support these objectives and policies the Fund grants the requested arrangement in accordance with the following provisions, and subject to the provisions applying to assistance under the Enhanced Structural Adjustment Facility Trust, as amended:

1. Under the second annual arrangement:

(a) the first loan, in an amount equivalent to SDR 9.578 million, will be available on June _, 1999 at the request of Albania,

(b) the second loan, in an amount equivalent to SDR 9.578 million, will be available after November $\rightarrow 1999$ at the request of Albania, subject to paragraph 2 below, and

(c) the third loan, in an amount equivalent to SDR 2.354 million, will be available after March, 2000 at the request of Albania, subject to paragraph 2 below.

2. Albania will not request disbursement of the second or third loan specified in paragraphs $1(\mathrm{~b})$ and $1(\mathrm{c})$ above:

(a) If the Managing Director of the Fund finds that, with respect to the second loan, the data as of September 30,1999 and, with respect to the third loan, the data as of March 31, 2000 indicate that:

(i) the floor on the net international reserves of the Bank of Albania or

(ii) the ceiling on the net domestic assets of the Bank of Albania, or

(iii) the ceiling on the banking system's net credit to the general government, including extra-budgetary funds, or

(iv) the limit on the contracting or guaranteeing by the government or the Bank of Albania of new nonconcessional external debt in maturities of one year up to and including fifteen years, or 
(v) the limit on the contracting or guaranteeing by the government or the Bank of Albania of new nonconcessional external debt in maturities of one year up to and including five years, or

(vi) the limit on the outstanding stock of nonconcessional external loans with maturities of less than one year contracted or guaranteed by the government or the Bank of Albania, referred to in paragraph 34 and specified in Table 1 of the Memorandum, was not observed; or

(b) if the Managing Director of the Fund finds:

(i) with respect to the second loan, that Albania has not carried out its intentions with respect to the completion of the SMEs privatization by sale, lease or liquidation of all but 50 of the remaining SMEs by September 30,1999, as specified in paragraph 23 and Table 2 of the Memorandum, or

(ii) with respect to the second loan, that Albania has not carried out its intentions with respect to the submission of a bill providing for the privatization of the Savings Bank to Parliament by September 30, 1999, as specified in paragraph 21 and Table 2 of the Memorandum, or

(c) if Albania:

(i) has imposed or intensified restrictions on payments and transfers for current international transactions, or

(ii) has introduced or modified multiple currency practices, or

(iii) has concluded bilateral payments agreements that are inconsistent with Article VIII, or

(iv) has imposed or intensified import restrictions for balance of payments reasons, or

(v) has incurred any new external payments arrears as specified in paragraph 34 and Table 1 of the Memorandum; or

(d) until the Fund has determined that with regard to the second loan, the first review of Albania's program scheduled for completion on February 29, 2000, and, with regard to the third loan the second program review scheduled for completion on May 31 , 2000 , referred to in paragraph 34 of the Memorandum has been completed.

When Albania is prevented from requesting disbursements under this arrangement because of this paragraph 2, such disbursements will be resumed only after consultation has taken 
place between the Fund and Albania and understandings have been reached regarding the circumstances in which Albania may request further disbursements.

3. Before approving the third annual arrangement, the Fund will appraise the progress of Albania in implementing the policies and reaching the objectives of the program supported by the second annual arrangement, taking into account primarily:

(a) the macroeconomics indicators and the structural benchmarks specified in Tables 1 and 2 of the Memorandum;

(b) the imposition or intensification of restrictions on payments and transfers for current international transactions;

(c) the introduction or modification of multiple currency practices;

(d) the conclusion of bilateral payments agreements that are inconsistent with Article VIII; and

(e) the imposition or intensification of import restrictions for balance of payments reasons.

4. In accordance with paragraph 3 of the Letter, Albania will provide the Fund with such information as the Fund requests in connection with the progress of Albania in implementing the policies and reaching the objectives of the program supported by this arrangement.

5. During the period of this arrangement Albania shall remain in close consultation with the Fund. In accordance with paragraph 3 of the attached letter, Albania will consult with the Fund on the adoption of any measures that may be appropriate at the initiative of the government or whenever the Managing Director of the Fund requests such a consultation. Moreover, after the period of this arrangement and while Albania has outstanding financial obligations to the Fund arising from loan disbursements under this arrangement, Albania will consult with the Fund from time to time, at the initiative of the government or whenever the Managing Director of the Fund request consultation on Albania's economic and financial policies. These consultations may include correspondence and visits of officials of the Fund to Albania or of representatives of Albania to the Fund. 
Mr. Michel Camdessus

Managing Director

International Monetary Fund

Washington, D.C. 20431

Dear Mr. Camdessus:

1. Despite the traumatic consequences for our country of the Kosovo crisis, the authorities of the Republic of Albania remain strongly committed to the policies that are being supported by a three-year arrangement under the IMF's Enhanced Structural Adjustment Facility (ESAF). Under the first-year economic program supported by the arrangement, the budget deficit was reduced as planned, inflation fell to a very low level, output rebounded, and our structural reform program was advanced. Since the review of the program was completed in January 1999, policies have remained on track and, according to preliminary data, all end-March 1999 indicative targets were met.

2. The large number of refugees from Kosovo does, however, impose a considerable burden on our economy. Without help from the international community - and, in particular, the provision of external budgetary grants to defray the substantial cost of providing for the refugees - it will become increasingly difficult to maintain macroeconomic stability and pursue our development objectives. In this context, we are therefore requesting a second annual arrangement under the ESAF and an augmentation of access under the arrangement by SDR 9.7 million ( 20 percent of quota) to provide continuing support to our comprehensive macroeconomic and structural adjustment program. The attached Supplementary Memorandum on Economic and Financial Policies describes the policies we will implement during the course of this arrangement. In collaboration with IMF and World Bank staff, we have also updated the Policy Framework Paper describing our three-year program.

3. The Government and the Bank of Albania believe that the policies outlined in the attached memorandum are adequate to achieve the targets of the program, but in consultation with the IMF, will take any further measures that may become necessary for this purpose during the program period. In addition, the authorities will provide the IMF with such information as the IMF may request in connection with the implementation of the policies and objectives of the program.

4. It is our desire to contribute to greater transparency of our policy commitments. Accordingly we plan to make public the attached Memorandum of Economic and Financial Policies. We also wish to participate in the pilot project on the release of staff reports for 
Article IV Consultations. We would ask that both documents be placed on the IMF internet web site.

Sincerely yours,

$/ \mathrm{s} /$

Pandeli Majko

Prime Minister

$/ \mathrm{s} /$

Anastas Angjeli

Minister of Finance
$/ \mathrm{s} /$

Shkëlqim Cani Governor, Bank of Albania

Attachment: Supplementary Memorandum of Economic and Financial Policies of the Government of the Republic of Albania 


\section{SUPPLEMENTARY MEMORANDUM OF ECONOMIC AND FINANCIAL POLICIES OF THE GOVERNMENT OF THE REPUBLIC OF ALBANIA}

\section{INTRODUCTION}

1. Before the eruption of the crisis in Kosovo in March 1999, macroeconomic and structural policies were consistent with the program supported by the ESAF arrangement, and macroeconomic developments were on track. The economy was recovering from the effects of the domestic upheavals in 1997 and macroeconomic stability had been restored. Despite a brief episode of civil disorder in September 1998, real GDP growth for 1998 is estimated to have been 8 percent, close to the targeted 10 percent. Inflation declined sharply to under 9 percent in the year to December 1998, and fell further to around 2 percent in the first few months of 1999. The lek has been broadly stable during the past 18 months, and the external current account deficit declined from 12 percent of GDP in 1997 to about 6 percent in 1998. Foreign exchange reserve cover was a comfortable 4.7 months of imports of goods and services at end-1998.

2. These positive economic developments reflected the government's steadfast adherence to macroeconomic stabilization policies. The domestically financed fiscal deficit was slightly below the target, and, at about $6 \frac{1}{2}$ percent of GDP, was over 4 percent of GDP below the 1997 outcome. Broad money was below the projected level for end-1998, and reserve money and net domestic assets of the Bank of Albania (BoA) actually fell during the year, reflecting an encouraging shift by the public from holding cash to bank deposits. Indicative targets for end-December 1998 and (according to preliminary data) end-March 1999 were met (Table 1).

3. In addition, structural reform has continued. The pyramid scheme companies are close to being wound up. A strengthened customs code was approved by parliament in April 1999. A foreign strategic buyer has been selected for the National Commercial Bank (NCB). More than 250 small- and medium-sized enterprises (SMEs) have been privatized, leased, or liquidated since September 1998. One of the four remaining former Enterprise Restructuring Agency (ERA) enterprises has been leased to a foreign investor, and government decisions have been adopted to liquidate two others. End-1998 targets for agricultural land registrations and transactions in the land market were met. Employment in budgetary institutions was reduced from about 145,000 at end-1997 to 133,000 at end-March 1999 .

4. The crisis in Kosovo and massive influx of refugees into Albania has, however, considerably changed key assumptions underlying the program and created intricate policy challenges. Already, about 430,000 refugees (13 percent of the local population) have entered the country and many more could arrive in the period ahead. While the government has welcomed the refugees, their growing number is imposing considerable pressures on fiscal resources because direct foreign aid covers only part of the costs associated with the refugees. Without adequate additional external financing, the government's development and reform program would be compromised. 
5. Despite the enormous pressures caused by the crisis in Kosovo, the government remains firmly committed to the objectives of maintaining macroeconomic stability, advancing structural reform, and strengthening governance. Economic policies will continue to be conducted in the framework of a medium-term program for April 1998-March 2001, for which the IMF is providing financial support under the ESAF. The remainder of this memorandum details the macroeconomic and structural policies for the period ahead. The government believes that, with enhanced external assistance, the policies set out below will be sufficient to achieve the program objectives, but it will take additional measures and seek new understandings with the IMF should the program diverge from its specified targets.

\section{The Government's Macroeconomic and Structural Policies}

\section{A. Objectives}

6. The crisis will not deflect the government from its task of helping to create the conditions for sustained rapid growth in a low-inflation environment. It will continue to implement far reaching structural reforms. Provided sufficient external assistance is made available to deal with the huge costs of the refugees, and provided the crisis is not exacerbated, annual growth should meet the 8 percent target for 1999. Inflation may rise temporarily from its current levels, owing to additional demand pressures on basic essentials, but the better-than-expected performance in recent months should ensure that it will remain below the program ceiling of 7 percent by end-year.

7. Macroeconomic policies will be kept consistent with maintaining inflation on a downward path such that broad convergence with rates in industrial countries is achieved in 2001. In particular, the government will preserve fiscal stability by limiting the domestically financed fiscal deficit to 5.5 percent of GDP in 1999, and steadily reducing it to 3 percent of GDP in 2001. Fiscal consolidation and structural reform are projected to be consistent with sustaining growth of around 8 percent in the medium term, while helping to put the balance of payments on a sustainable footing. Although gross reserves may decline in 1999, reserve cover will be kept above $31 / 2$ months of imports of goods and services. Specific targets for 1999 and 2000 are tabulated below.

\begin{tabular}{|c|c|c|c|c|c|}
\hline & \multicolumn{2}{|l|}{1998} & \multicolumn{2}{|c|}{1999} & \multirow[t]{2}{*}{2000} \\
\hline & $\begin{array}{l}\text { Orig.Prog. } \\
\text { (Apr. 1998) }\end{array}$ & Est. & $\begin{array}{l}\text { Orig.Prog. } \\
\text { (Apr.1998) }\end{array}$ & Rev. & \\
\hline GDP growth (in percent) & 10 & 8 & 7 & 8 & 8 \\
\hline Inflation (during period; in percent) & 10 & 9 & 7 & 7 & 5 \\
\hline $\begin{array}{l}\text { End-period gross official reserves } \\
\text { (In millions of U.S. dollars) } \\
\text { (In months of imports of goods }\end{array}$ & 340 & 385 & 360 & 375 & 390 \\
\hline and services) & 3.8 & 4.7 & 3.7 & 3.7 & 3.7 \\
\hline External current account deficit (in & & & & & \\
\hline Percent of GDP) & 13.8 & 6.1 & 11.2 & 12.0 & 8.6 \\
\hline
\end{tabular}




\section{B. Fiscal Policy}

8. The Kosovo crisis will not deflect the government from the pursuit of sound fiscal policies. The government is receiving assurance from the international community that additional budget expenditures for the provision of assistance to the refugees will be financed by external grants and highly concessional credits. This will enable the government to keep to its original budget objective of reducing the domestically financed budget deficit from $61 / 2$ percent of GDP in 1998 to $5 \frac{1}{2}$ percent of GDP in 1999 without having to make cutbacks in essential social and economic development spending and without having to incur sizable future debt service payments. Taking into account the higher external financing, however, the overall deficit, is projected to rise to 13.8 percent of GDP in 1999 from 10.4 percent of GDP in 1998. The government believes that the measures described below are sufficient to achieve the fiscal targets, but is prepared to take additional steps as needed. In particular, the government will intensify its tax collection efforts and, if necessary, raise taxes and cut current spending to prevent any slippage. As the economic impact of the Kosovo crisis is particularly difficult to predict, the government, in consultation with IMF staff, will keep the fiscal stance and fiscal developments under continuous review. A further reduction in the domestically financed deficit to about 4 percent of GDP will be embedded in the 2000 budget. Passage by parliament of a satisfactory 2000 budget will be a condition for completing the mid-year review of the program under the second annual ESAF arrangement.

9. In line with the medium-term fiscal strategy, underlying fiscal consolidation in 1999 will rely on measures to raise tax revenue by the equivalent of about $11 / 2$ percent of GDP. Part of the increase will result from measures taken to modernize the tax system through a new direct tax law and from the solidarity tax (a surcharge on profit and income taxes). Among other things, the direct tax law introduced a 10 percent withholding tax on interest income, raised personal income tax rates, included bonuses in the personal income tax base, and abolished some tax holidays. The government will not introduce new direct tax holidays, including for companies in any planned free zones, nor introduce exemptions from VAT or customs duty (structural benchmark). Other tax changes, including the unification of excise taxes on domestic and imported goods, will be at least revenue neutral, while improved import valuation methods will offset the cost of a reduction in tariff rates (see paragraph 32).

10. Revenue increases will also result from measures to strengthen customs and tax administration. The Kosovo crisis will not loosen the government's resolve to implement these measures effectively. In the area of customs administration, the government will continue its cooperation with the EU Customs Assistance Mission to Albania in order to reduce smuggling, fraud, and corruption, and raise collections, including through better enforcement of taxation of imports carried by individuals. The passage in April 1999 of a substantially strengthened customs code provides a suitable legal framework to address governance problems in the customs area. As a prior action for the Board meeting for the second annual ESAF arrangement, the revised code will be implemented by: (i) activating the post-clearance unit in the Customs Directorate; (ii) restructuring and inreasing the resources available to the internal audit unit in the Customs Directorate; and (iii) finalizing a plan for 
collecting customs debts and beginning its implementation. To reduce fraud and corruption the government will strictly implement the rules for transparency in the recruitment of customs officials and seek assistance from neighboring countries to continue providing prearrival information on exports to Albania. Along with the implementation of the new customs code, the government will also help to combat smuggling by employing 40 anti-smuggling officers hired from outside the Customs Directorate (prior action for the Board meeting). The government will hire a further 60 anti-smuggling officers by end-1999 (structural benchmark). Improving the valuation of imports for customs purposes is also a prior action for the Board meeting. To this end, the government will adjust reference prices for the valuation of imports in line with market prices, increasing in particular those prices which are currently underestimated. An exception will only be allowed in the case of diesel, for which current minimum reference prices for imports may continue to apply until end-October 1999. The government will also aim to make the customs reference valuation file fully operational in all major customs clearance houses by end-1999 (structural benchmark).

\section{As for tax administration, a new law on tax administration that will make tax} procedures more transparent and strengthen enforcement will come into force at end-July 1999. Moreover, VAT documentation is being improved (through turning VAT receipts into secure paper, to be introduced by end-June 1999), 7 additional tax offices are being computerized with funds already approved under the Tax Administration and Modernization Project, and training for tax officials and taxpayer education has been increased. The government will also work with the World Bank to improve the operations of the large taxpayers' office.

12. Delays in the passage of the customs code and in strengthening tax administration led to some shortfalls in revenue in the first quarter of 1999 relative to budget targets. The shortfall was compounded in April by a logjam of humanitarian and military imports at the main ports, which has delayed the import of taxable commercial goods. Assuming the logistical problems in the ports can be resolved quickly, and now that the measures to strengthen tax and customs administration are entering into force, the government is determined that there will be no further slippage in revenue collection in the remainder of the year. Effective July 1, increases in local property taxes (which have been unchanged since 1994 and the imposition of excise taxes on tires and cosmetics will also help to recover some of the earlier revenue losses such that revenues are projected to fall short of the full-year budget target by no more than lek 1.5 billion (US\$10 million). Tax collection will be monitored under the program by way of quarterly indicative floors (Table 1). The authorities will review revenue developments with IMF staff on a monthly basis to identify any underlying weaknesses in tax collection and, if necessary, to agree on corrective measures to ensure that tax collection remains consistent with the quarterly floors.

13. Total expenditure, which was originally budgeted to remain around 31 percent of GDP, is now projected to rise to about 35 percent of GDP in 1999 as a result of the government's contribution to assisting the refugees. The projection assumes that the number of refugees in Albania will peak at about 500,000 in May and decline only moderately in the remainder of the year. The budgetary cost, equivalent to about US\$144 million, includes sizable outlays for health, education, family assistance to the nearly 300,000 refugees being 
cared for in Albanian homes, provision of sanitation and other services in refugee centers, conversion of public buildings into refugee shelters, policing, and construction and maintenance of roads and other supporting infrastructure. These expenditures are in addition to those being borne by international relief agencies, which have been overwhelmed by the immense number and speed of arrival of the refugees. The estimated budgetary costs have been made conservatively in consultation with the staffs of the World Bank, IMF, and international development agencies. For example, they do not factor in the potentially much greater cost of caring for the refugees as winter approaches. There is also a significant likelihood that the number of refugees could be markedly higher. In view of the high degree of uncertainty in projecting refugee numbers and costs, the government, in consultation with IMF staff, will update its estimates of budgetary costs on a regular basis and keep the donor community informed of any revisions to external financing needs.

14. In consultation with IMF and World Bank staff, the government will ensure flexible, transparent and accountable use of budgetary funds for humanitarian relief. Specifically, it will: (i) prepare an outline of the Budget Framework Memorandum for allocating budgetary resources on a bi-monthly basis, starting in May 1999; (ii) add separate expenditure categories temporarily to the budget classification; (iii) establish a monitoring mechanism for the use of budgetary funds allocated to the relief efforts and submit bi-weekly reports to the Ministry of Information, which will make them available to the public and the donor community; (iv) establish a budgetary account in the Savings Bank for all financial aid donated to the government to cover relief efforts ("The Kosovo Account"); and (v) implement guidelines and procedures requiring full budget and treasury procedures for the allocation, execution, accounting, and reporting of funds in the Kosovo Account.

15. Excluding spending on the refugees, the original budget for 1999 allowed for a shift in the composition of expenditure from current to capital expenditure. Non-refugee-related current spending declines relative to GDP, largely because of lower interest payments on domestic debt, but also because of determined efforts to keep personnel expenditures in check and to improve the targeting and delivery of social assistance. To contain wage costs, the general wage increase was limited to 10 percent, and delayed until May 1, 1999, while budgetary employment will be reduced by $3 \frac{1}{2}$ percent, with the expenditure savings being used to cover the costs of further wage decompression (paragraph 26). To ensure better targeting of social assistance, only 35 percent of the 1999 budget allocation will be released by end-June 1999, by which time the Ministry of Labor and Social Affairs will have compiled a comprehensive database on recipient families. However, while improved monitoring of benefits and better economic conditions should generate savings on social assistance without weakening the economic position of those in need, the government will make available additional resources for social assistance from the reserve and contingency funds if the number of eligible families does not fall as expected. Expenditure on investment and operations and maintenance is budgeted to increase by 20 percent in 1999. Despite the increase, such expenditure remains too low in view of the great need to improve and extend the infrastructure. The government is committed to raising expenditures on investment and other priority items, including health and education, over the medium term. Without adequate external budgetary grants and concessional financing to pay for the costs of assisting the 
refugees, the government will be forced to scale back spending on investment and essential social services.

\section{The government will continue to improve budgetary procedures and public} expenditure management. The 1999 budget was prepared according to the new organic budget law, with more transparent procedures. The government will seek technical assistance from the IMF, World Bank, and the EU to improve budget classification which will be used in the preparation, execution and reporting of the 2000 budget. The cash management system in the treasury department will be improved further in 1999. During 1999, the government will take steps to integrate the investment and recurrent budget planning processes.

\section{Monetary and Exchange Rate Policies}

17. Provided sufficient external assistance is made available to finance refugee-related government expenditures, the Kosovo crisis should have a limited impact on monetary conditions. The Bank of Albania (BoA) will continue to maintain an appropriately tight monetary stance to help reduce inflation, its main objective. The minimum deposit rates for state-owned banks will be kept at levels which are positive in real terms, with the timing and amount of nominal rate changes being based on an assessment of price developments, the demand for lek deposits, and conditions in the foreign exchange market. The BoA will continue to operate under a flexible exchange rate regime. Intervention will be limited to that necessary to smooth excessive fluctuations in the exchange rate. While maintaining adequate reserve cover, the BoA will also release foreign exchange derived from inflows of foreign assistance in order to provide resources for imports, timing its release to avoid excessive volatility in the exchange market.

18. The monetary program for 1999 is geared to ensuring that broad money expansion remains consistent with the inflation objective. On the assumption of a broadly constant velocity during 1999 , and given projected nominal GDP growth, this would imply broad money growth of about 15 percent. This expansion should be sufficient to meet the needs of the budget, and also allow a significant increase in credit to the private sector. Quarterly indicative targets and performance criteria are contained in Table 1.

19. The BoA intends to start to replace bank-by-bank credit ceilings with indirect instruments of monetary policy in the course of 1999. A necessary condition for the removal of the ceilings will be strong banking supervision to monitor and constrain, if needed, individual banks. The BoA intends to strengthen banking supervision during 1999 , including by improving both on- and off-site supervision techniques (see paragraph 22 ). This should permit the phasing out of credit ceilings on banks that meet clearly stated prudential requirements. For banks not meeting such requirements, including having a proportion of overdue loans of more than 30 days in excess of 20 percent of their portfolio, no increase in net credit will be permitted, and lending proposals will be subject to strict review. The BoA will be discussing with a forthcoming IMF technical assistance mission the adequacy of banking supervision, means of developing the treasury bill market, reserve money management, the payments system, and the potential for developing an interbank credit market. The BoA will, by end-June 1999, organize a seminar for banks to discuss interbank 
lending. To facilitate the move towards indirect monetary policy instruments, the BoA and the Ministry of Finance have established a joint committee which coordinates the issuance of treasury bills and arrangements for profit transfers to the government. During 1999, the committee will meet each month. Furthermore, the BoA intends to set up a Credit Information Bureau by end-September 1999 to make transfer of information among banks easier and to facilitate lending to creditworthy customers.

\section{Structural Policies}

20. The process of winding up the pyramid scheme companies, whose collapse precipitated the crisis of March 1997, is progressing. Foreign accounting firms appointed to administer and audit the companies have offered all the seized assets for sale and one of the auditors' final reports of the companies was presented in May 1999. The government has already made an initial distribution of the proceeds of the asset sales, and aims to complete the sale and distribution of all remaining assets by end-1999.

21. The government will make significant progress in privatizing the two remaining state-owned banks in 1999. A privatization advisor has been appointed for the National Commercial Bank (NCB), and, following the submission of two tenders, the government selected a buyer in April 1999. As prior actions for the Board meeting for the second annual ESAF arrangement, the government will prepare decisions on (i) recapitalization of the bank, (ii) transfer of the bank's loan portfolio to the Loan Collection Agency, and (iii) transfer of NCB's shareholdings in other banks to the Ministry of Finance. A sale contract is expected to be signed by end-June 1999, with final legal arrangements for the privatization of the bank, including the clean up of its balance sheet, to be completed by end-September 1999. The Savings Bank is now operating under a governance contract. Cooperation between the bank, its advisors, and the government has been good, and the advisors have prepared an action plan to streamline the bank's operations in preparation for privatization. For its part, the government will, by end-September 1999, agree on a plan for the privatization of the Savings Bank in consultation with the World Bank, and submit to parliament a draft law for its privatization (structural performance criterion). The government will also discuss with the Savings Bank the amount of compensation for agency services conducted on the government's behalf, and raise payments for agency services to commercial rates by endSeptember 1999. The government intends to initiate the privatization process in 1999 and select a buyer for the Savings Bank no later than end-March 2000 (structural benchmark).

22. The government and the BoA are continuing to take steps to clarify and strengthen the legal, regulatory, and supervisory framework under which the banks operate. The $\mathrm{BoA}$ is in the process of drafting a Law on Secured Transactions to facilitate collateralized lending, which will shortly be sent to the Council of Ministers, and to parliament by end-June 1999 (structural benchmark). The draft Money Laundering Law will incorporate IMF comments and be sent to the Council of Ministers by end-June 1999. Enforcement of the Companies Law and the Bankruptcy Law is being improved through additional training of the judiciary, with assistance from the World Bank and other donors. In the area of banking supervision, a legal framework and a set of core prudential regulations broadly in line with the Basle Core Principles has been adopted and licensing requirements for new banks and 
capital adequacy requirements for all banks are being strengthened. With IMF technical assistance, the BoA will, during 1999, hold a training program in banking supervision in order to develop its institutional capacity to implement the new regulations and, in particular, strengthen its ability to conduct off-site supervision. To improve the payments system, the BoA has introduced SWIFT communication with commercial banks and preparations are underway to adopt a large-value transfer system in the form of a real-time gross settlement system. Moreover, the Savings Bank has concluded agreements with Italian and Greek banks to allow low-cost transfer of remittances from Albanians in Italy and Greece, and an agreement with Moneygram to provide facilities for transfer from these and other countries.

\section{The government will take every step to accelerate enterprise privatization and} restructuring. As prior actions for the Board meeting for the second annual ESAF arrangement, the remaining ERA enterprises and at least 300 of the 469 small- and mediumsized enterprises (SMEs) which remained at end-September 1998 will be privatized, leased, or liquidated. The remaining SMEs will be sold, leased, or liquidated by end-September 1999, with the exception of about 50 enterprises which are being retained in the public sector for national security or social reasons (structural performance criterion). At the same time, the government remains committed to the privatization of the strategic enterprises. The first candidate for sale is the mobile telephone company (AMC). A privatization advisor has been appointed and invitations for tenders will be sent to interested buyers with a view to selecting a buyer by end-1999 (structural benchmark). The government will initiate the privatization of the fixed telecommunications company (Telekomi Shqiptar) by end-1999. In the mining sector, the government will invite the World Bank to coordinate a financial assessment of the chromium and copper mines. The government will sell or liquidate all small copper and small chromium mines by end-September 1999 (structural benchmark). In addition, a draft law for the privatization of Albchrom and Albbaker will be finalized in consultation with the World Bank and enacted by end-September 1999 (structural benchmark), with a view to initiating privatization in the fourth quarter of 1999 and completing privatization or liquidation of the companies by end-March 2000. In the petroleum sector, Albpetrol has been split into three companies, which are being prepared for privatization. To cut costs, the government will close unviable operations and reduce employment in the sector by 2,000 to 7,500 by March-2000. In consultation with the World Bank, the government will pass laws for the privatization of the service company and the refining and marketing company by endSeptember 1999. It is the government's aim to complete the privatization of the service company and initiate the privatization of the refining and marketing company by end-1999. The government will begin the privatization of the exploration and production company in 2000.

24. By end-May 1999, the government, in coordination with the World Bank, will prepare a financial forecast which will clarify the financial position of the electricity utility, $\mathrm{KESH}$, and propose measures to reduce losses and supply disnuptions, and improve collection. The plan will include measures to strengthen the management of KESH, including through an incentive-based foreign governance contract. It will also include: (i) a clear financial plan for 1999 and later years; (ii) quarterly targets for reducing theft, improving collections, and disconnection of customers in arrears; and (iii) measures to facilitate 
payment of bills. The government will ensure the installation of at least 900 meter boxes per quarter, beginning end-March (structural benchmark). Government approval will be required for any borrowing or barter agreement entered into by KESH.

25. The government has made considerable progress in creating a well-functioning agricultural land market, which is essential to improvements in productivity and consolidation of landholdings, and will take further steps to develop the land market in 1999. In particular, the government will provide adequate office space for land registries and set up and provide funding for special validation commissions which can provide tapis (land use certificates) in villages where these were not issued. Progress in land registration and the establishment of a land market will be monitored by quarterly benchmarks on the number of cadastral zones for which first registration should be completed and on the number of land sale transactions. These benchmarks are described in Table 2.

\section{The government will make further progress in the reform of public administration} and the civil service in 1999. Budgetary sector employment will be reduced from 133,000 at end-March 1999 to 130,000 by end-1999 in order to free resources to increase wage differentiation (structural benchmark). During 1999, employment monitoring will be improved through enhancements to the database of budgetary employment in the Department of Public Administration and through better coordination between the Department of Public Administration and the Treasury Department. In late 1998, the Council of Ministers issued a decision to conduct functional reviews in four agencies (the central administration and the Ministries of Finance, Justice, and Local Government). With external assistance, the review of the central administration was completed in March 1999. Reviews of the other three ministries and the Ministry of Education will be completed by end-1999.

27. The government is determined to continue the fight against corruption. In addition to the measures to strengthen the customs administration (paragraph 10) in September 1998 the government formally adopted an anti-corruption strategy, which it intends to implement fully. To improve transparency, the government will, by end-June 1999, modify procedures to increase the frequency of verification of the declaration of personal assets by ministers and senior officials. The government will also, by end-September 1999, display approved fees for government services publicly. To strengthen the judiciary, the government will, by endDecember 1999, test all judges and remove those who fail the test, and will strengthen the functioning of the judicial inspection office in the High Council of Justice.

\section{E. External Sector Policies and Program Financing}

28. The external current account deficit is projected to rise sharply from 6 percent of GDP in 1998 to 12 percent of GDP in 1999 mainly as a result of higher import demand arising from the effects of the Kosovo crisis and from investment and reconstruction needs. Excluding humanitarian imports financed by direct aid, imports are projected to grow by 28 percent in 1999 while the rapid growth in exports expected before the crisis will be dampened somewhat by supply disruptions in the north of the country and some switching to local markets. A decline in the current account deficit to $81 / 2$ percent of GDP is projected for 
2000 on the assumption (which may prove optimistic) that imports related to the Kosovo crisis will decline sharply and export growth will strengthen.

29. On the basis of current commitments from bilateral and multilateral donors, and the expectation that inflows of direct investment will remain at a low level because of the uncertainty created by the Kosovo crisis, additional exceptional financing will be needed in 1999 to finance the current account deficit and maintain adequate reserve cover. Taking into account a new US\$30 million public expenditure support credit from the World Bank and a one-year nonconcessional deferral of all debt service to Paris Club creditors, the residual financing gap for 1999 is estimated at US $\$ 119$ million. The EU has pledged a budgetary grant of Euro 62 million (US\$65 million). The government will request additional assistance from multilateral and bilateral donors at a donors conference scheduled for the second half of May. Assuming that the Kosovo crisis does not exert a continuing negative influence on the balance of payments, financing gaps in 2000 and beyond are more modest-on the order US\$40-50 million a year. Additional support will be needed to close these gaps. The external financing of the program will be reassessed during the mid-year review.

30. The government will take further steps to regularize relations with external creditors. The government will conclude bilateral agreements under the July 1998 Paris Club agreement for rescheduling Albania's debt in arrears to Russia and Italy as soon as possible and seek at least comparable treatment from non-Paris Club official bilateral and commercial creditors with outstanding claims on Albania. The government will continue efforts toward the removal of the remaining restrictions subject to IMF approval under Article VIII, Section 2(a), in the form of outstanding debit balances under inoperative bilateral payments agreements.

31. The government intends to improve aid monitoring and absorption in the period ahead. An operational external debt database and a similar database for grants will be completed by end-June 1999 and the government will, with external technical assistance, formalize the procedural, institutional, and legal framework for monitoring and servicing external credits and grants by end-1999. The Ministry of Finance has appointed a foreign grants officer. The government will ensure timely and accurate reporting of external debt, including commitments by state-owned enterprises. To strengthen absorption capacity and remove obstacles to the disbursement of foreign aid, the government will continue to simplify procedures relating to the approval of foreign financed projects, and provide adequate funds for reimbursement of VAT and customs duty and for land acquisition.

32. The government remains committed to trade reform and to maintaining a liberal trade regime. A key objective in this regard is to lower the average tariff rate over the medium term through a combination of reductions in the level, number, and dispersion of rates. The medium-term aim will be to achieve a simple and transparent tariff structure with relatively low (fiscal considerations permitting, close to a 10-12 percent unweighted average tariff rate, compared with the present 15.9 percent) and more uniform tariff rates. As an initial step, the maximum tariff rate was reduced from 30 percent to 20 percent in April 1999. The government intends to lower the maximum tariff rate further to 18 percent in the 2000 budget. The government will also reverse the recent increase in the tariff on diesel back to 
10 percent by end-October, 1999 and will not introduce any new protectionist measures for the domestic petroleum industry, including the differentiation of excise taxes by the quality of diesel. In addition, the government will remove the export bans on skins and hides, and on the remaining two scrap metals, by end-July 1999 (structural benchmarks). It is committed to not introducing any new quantitative restrictions on exports or imports.

\section{F. Economic Statistics}

33. The government and the BoA will continue efforts to improve the quality, coverage, and timeliness of economic and financial data. To address the key deficiencies, the authorities will implement a work program that was prepared in collaboration with a multitopic mission from the IMF Statistics Department in February 1999. By end-June 1999, the authorities will establish an inter-agency Statistics Council headed by the Institute of Statistics (INSTAT) and including representatives of the Ministry of Finance, the BoA, the Customs Directorate and other agencies, which will formulate statistical policies, coordinate the production of statistical data, and have the authority to request budgetary resources for statistical work (structural benchmark). One of the key objectives of the council will be to prepare the ground for Albania's participation in the General Data Dissemination System (GDDS), which is currently impeded only by a lack of adequate national accounts. Accordingly, the government has requested external assistance, including a short-term expert, and will also recruit additional staff for INSTAT's national accounts unit.

\section{Program Monitoring}

34. During the second annual ESAF arrangement, the program will be monitored based on quantitative performance criteria and indicative targets for end-September 1999 and endMarch 2000, and indicative targets for end-June and end-December 1999, set on a cumulative basis from end-December 1998 (Table 1), and structural performance criteria and benchmarks (Table 2). The government will conduct with the IMF a mid-year review of the program no later than end-February 2000 that will, among other things, require for completion a satisfactory agreement with IMF staff on a 2000 budget, and an end-year review to be completed no later than end-May 2000. The quantitative targets include: (i) a floor on the net international reserves (NIR) of the BoA; (ii) a ceiling on the net domestic assets (NDA) of the BoA; (iii) a ceiling on the banking system's net credit to the general government (including extra-budgetary funds); (iv) a ceiling on the contracting or guaranteeing by the public sector of new nonconcessional medium- and long-term external debt in the maturity range 1-15 years, with a subceiling on the contracting or guaranteeing of new nonconcessional external debt in the maturity range 1-5 years; and (v) a ceiling on the stock of outstanding short-term external debt, with the exception of normal import-related credits. The NIR floor will be adjusted upward and the NDA and net credit to government (NCG) ceilings downward for any excess in balance of payments or external budget financing (including budgetary grants for humanitarian relief to refugees from Kosovo) above program projections and/or any shortfall of the Kosovo-related budget cost from program projections. The NIR floor will be adjusted downward and the NDA and NCG ceilings upward to the extent that there is any shortfall in balance of payments or budget 
financing from program projections and/or any excess of the Kosovo-related budget cost from program projections, with the proviso that the downward adjustment to the NIR floor shall not exceed US\$50 million and the upward adjustment to the NDA and NCG ceilings shall not exceed the lek equivalent of US\$50 million, converted at the program monitoring exchange rate. The ceilings on NCG will also be adjusted downward for any excess in privatization receipts over the program levels (Table 1). Collection of tax revenue will be monitored on the basis of quarterly indicative floors. During the program period, Albania will not impose or intensify exchange restrictions on current transactions or import restrictions for balance of payments reasons, and will not accumulate new external payments arrears, except for obligations for which a rescheduling is expected. 


\section{Table 1. Albania: Performance Criteria and Indicative Targets for 1999-2000 1/}

\begin{tabular}{|c|c|c|c|c|}
\hline $\begin{array}{l}\text { End-Dec. } \\
\text { levels } 1998\end{array}$ & $\begin{array}{l}\text { End-June } \\
\quad 199921\end{array}$ & $\begin{array}{l}\text { End-Sep. } \\
\quad 19993 /\end{array}$ & $\begin{array}{l}\text { End-Dec. } \\
19992 /\end{array}$ & $\begin{array}{l}\text { End-Mar. } \\
20003 /\end{array}$ \\
\hline Actual & Prog. & Prog. & Prog. & Prog. \\
\hline
\end{tabular}

1. Net banking system credit to the government $4 / \mathrm{S} /$

2. Net domestic assets of the $\mathrm{BoA} 4 / 6 /$

3. Tax revenues $7 /$

4. Net international reserves of the BoA 8/

5. Contracting or guaranteeing of non-concessional external debt with maturities $1-15$ years $4 / 9 /$ Of which: $1-5$ years $4 / 9 /$

6. Public and publicly-guaranteed external debt with maturities of up to 1 year $4 / 10 /$
(In billions of leks)

\begin{tabular}{rrccc}
176 & 10 & 19 & 28 & 33 \\
60.7 & 9 & 13 & 18 & 21 \\
$\ldots$ & 29 & 50 & 73 & 90 \\
& & \multicolumn{2}{c}{ (In millions of U.S. dollars) } \\
194.7 & -33 & -29 & -31 & -38 \\
& & & & \\
$\ldots$ & 20 & 30 & 40 & 50 \\
$\ldots$ & 5 & 5 & 10 & 10
\end{tabular}

1/ Unless otherwise noted, all targets are expressed as cumulative changes from end-December 1998 levels. There is also a continuous performance criterion on the non-accumulation of new external arrears exclusive of arrears that are subject to rescheduling consistent with the July 1998 Paris Club terms of reference.

2/ Indicative targets.

3/ Performance criteria.

4/ These figures represent a ceiling.

5/ These include extrabudgetary accounts as defined in the technical memorandum of understanding. The limits on the net bank credit to the government are adjusted downwards (upwards) by any amount by which total foreign financing (excluding project and commodity loans) to the budget exceeds (falls short of) the amounts assumed in the program (the lek equivalent of US\$87 million during January 1, 1999 to June 30, 1999; US\$144 million during January 1, 1999 to September 30, 1999; US\$193 million during January 1, 1999 to Decernber 31, 1999; and US $\$ 229$ million during January 1, 1999 to March 31,2000 , to be valued at the program monitoring exchange rate of 140.58 leks per U.S. dollar) and/or any amount by which the Kosovo-related budget cost is lower than (exceeds) the amounts assumed in the program (the lek equivalent of US\$65 million during January 1, 1999 to June 30, 1999; US\$112 million during January 1, 1999 to September 30, 1999; US\$155 million during January 1, 1999 to December 31, 1999; and US\$181 million during January 1, 1999 to March 31, 2000, to be valued at the program monitoring exchange rate), with the proviso that the upward adjustment to the ceiling should not exceed the lek equivalent of US\$ 50 million, converted at the program monitoring exchange rate. The limits are adjusted downward for any excess in privatization proceeds over the programmed levels of 1.3 billion leks during January 1, 1999 to June 30, 1999; 2.2 billion leks during January 1, 1999 to September 30, 1999; 3.0 billion leks during January 1, 1999 to December 31,1999; and 4.0 billion leks from January 1, 1999 to March 31,2000. The limits are also adjusted by any changes in the net holdings of government debt of INSIG, other nonfinancial corporations or state enterprises.

6/ In parallel with the adjustments described in footnote 5, the limits on NDA are reduced (increased) by the lek equivalent of any excess (shortfall) in foreign financing and/or any amount by which the Kosovo-related budget cost is lower than (or exceeds) the program assumptions, with the proviso that the upward adjustment to the ceiling should not exceed the lek equivalent of US\$ 50 million, converted at the program monitoring exchange rate. The targets will be adjusted to reflect the impact of any change in the required reserve ratio.

7/ All indicative targets, representing a floor. Tax revenues are defined as revenues collected by the central tax department and the customs department.

8/ These figures represent a floor, to be increased (decreased) by the amount of any balance of payments support in excess of (or lower than) the program assumptions (US\$108 million during January 1, 1999 to June 30, 1999; US\$177 million during January 1, 1999 to September 30, 1999; US\$226 million during January 1, 1999 to December 31, 1999; and US\$287 million during January 1, 1999 to March 31, 2000) and/or any amount by which the Kosovo-related budget cost is lower than (exceeds) the program assumptions, with the proviso that the downward adjustment shall not exceed US\$50 million. The figures exclude holdings of nonconvertible currencies, claims on nonresident financial institutions denominated in convertible currencies; foreign currency reserves of commercial banks held at the Bank of Albania and credit and debit balances as of December 31, 1998, arising from bilateral payments agreements in clearing dollars and in rubles, and any foreign liabilities arising from debt rescheduling operations.

9/ This limit applies to debts contracted or guaranteed by the government, state-owned enterprises, or the Bank of Albania, and excludes changes in indebtedness resulting from refinancing credits and rescheduling operations (including the deferral of interest on commercial debt), credits extended by the IMF and credits on concessional terms, i.e., those with a grant element of 35 percent or more calculated using the OECD Commercial Interest Reference Rates (CIRRs) for January 16-February 15, 1999.

10/ This limit applies to short-term debt contracted or guaranteed by the government, state-owned enterprises, or the Bank of Albania. Excluded from the limits are changes in indebtedness resulting from rescheduling operations (including the deferral of interest on commercial debt), and normal import-related credits. Debts falling within the limit shall be valued in U.S. dollars at the exchange rate prevailing at the time the contract becomes effective. The end-December 1998 stock of short-term debt includes already outstanding debts with maturities of $1-5$ years. The figures exclude external debt in arrears for which a rescheduling is expected, or which is in dispute.

CInternational Monetary Fund. Not for Redistribution 
Table 2: Albania: Prior Actions, Structural Performance Criteria, and Structural Benchmarks for the Second Annual ESAF Arrangement

\section{Prior actions}

1. Enact the amendments to the customs code submitted to parliament in early March 1999 and implement the revised customs code by (i) activating the post-clearance control unit in the Customs Directorate (CD); (ii) restructuring and increasing the resources available to the internal audit unit in the $\mathrm{CD}$; and (iii) finalizing a plan for collecting customs debts, and beginning its implementation.

2. Employ 40 anti-smuggling officers hired from outside the $\mathrm{CD}$.

3. Adjust reference prices for the valuation of imports in line with market prices (an exception can be made for the price of diesel), increasing in particular those prices which are currently underestimated.

4. Select a buyer for the National Commercial Bank, and prepare government decisions on (i) recapitalization of the bank; (ii) transfer of the bank's loan portfolio to the Loan Collection Agency; and (iii) transfer of NCB's shareholdings in other banks to the Ministry of Finance.

5. Sell, lease or liquidate all remaining former Enterprise Restructuring Agency enterprises and at least 300 of the 469 small- and medium-sized enterprises (SMEs) which remained unsold at end-September 1998.

\section{Structural performance criteria}

1. Complete the process of SME privatization by sale, lease or liquidation of all but 50 of the remaining SMEs (end-September 1999).

2. Submit to parliament a draft law for the privatization of the Savings Bank (endSeptember 1999).

\section{Structural benchmarks}

1. No new exemptions from VAT or customs duty (throughout).

2. Employ a further 60 anti-smuggling officers hired from outside the CD (end-December 1999).

3. Select a buyer for the Savings Bank (end-March 2000).

4. Submit a draft Law on Secured Transactions, acceptable to the Fund, to parliament (end-June 1999). 
5. Select a buyer for Albanian Mobile Communications (end-December 1999).

6. Sell or liquidate all small copper and small chromium mines, and enact a law allowing the government to privatize the remaining Albchrom and Albbaker mines (end-September 1999).

7. Install at least 900 electricity meter boxes in the second quarter of 1999 , and a further 900 meter boxes in each subsequent quarter of 1999 .

8. Complete first registration in 900 cadastral zones by end-June 1999, in 1,050 cadastral zones by end-September 1999, in 1,200 cadastral zones by end-December 1999, and in 1,350 cadastral zones by end-March 2000 .

9. Complete at least 3,000 sales transactions in agricultural land by end-June 1999, at least 3,500 by end-September 1999 , at least 4,000 by end-December 1999 , and at least 4,500 by end-March 2000 .

10. Reduce budgetary employment to 130,000 or below (end-December 1999).

11. Remove all remaining export bans (end-July 1999), with no new import or export bans to be imposed (throughout).

12. Reverse the increase in the import tariff on diesel and abolition of minimum reference prices for diesel (end-October 1999).

13. Improve the valuation of imports through making the customs reference valuation file fully operational in all major customs clearance houses.

14. Form Inter-Agency Statistics Council and approve terms of reference in line with recommendations of the recent multisector statistics mission from the IMF Statistics Department (end-June 1999). 


\section{INTERNATIONAL MONETARY FUND}

EXTERNAL

Public Information Notice

RELATIONS

DEPARTMENT

Public Information Notice (PIN) No. 99/51

For Immediate Release

International Monetary Fund

June 22, 1999

Washington, D. C. 20431 USA

\section{IMF Concludes Article IV Consultation with Albania}

On June 14, 1999, the IMF Executive Board concluded the 1999 Article IV consultation ${ }^{1}$ with Albania and approved the second annual arrangement under the Enhanced Structural Adjustment Facility, providing the equivalent of SDR 21.5 million (about US $\$ 30$ million) to support the government's 1999/2000 program.

\section{Background}

Prior to the crisis in neighboring Kosovo, which erupted at end-March 1999, the Albanian economy was making a successful recovery from the impact of civil disturbances in 1997 brought about by the collapse of the pyramid schemes. Growth is estimated to have been 8 percent in 1998, reversing the 1997 decline in output, and inflation declined to 8.7 percent from 42 percent in 1997. Inflation fell further to 2 percent in March 1999. The return to growth and low inflation reflected the govemment's adherence to strong fiscal consolidation efforts: the domestically financed component of the deficit was reduced to 6.4 percent of GDP in 1998 from 10.8 percent of GDP in 1997. The external current account deficit also fell sharply from 12 percent of GDP in 1997 to 6 percent of GDP and foreign reserves climbed to 4.7 months of imports at end-1998.

Structural reforms were also progressing. Foreign administrators of the pyramid scheme companies completed their work and handed over to their local counterparts. In the banking sector, the authorities prepared the National Commercial Bank (NCB) for privatization and placed the Savings Bank under a foreign governance contract. In the enterprise sector, a further $\mathbf{4 5 0}$ small- and medium-sized enterprises were privatized and one of the four remaining

${ }^{1}$ Under Article IV of the IMF's Articles of Agreement, the IMF holds bilateral discussions with members, usually every year. A staff team visits the country, collects economic and financial information, and discusses with officials the country's economic developments and policies. On return to headquarters, the staff prepares a report, which forms the basis for discussion by the Executive Board. At the conclusion of the discussion, the Managing Director, as Chairman of the Board, summarizes the views of Executive Directors, and this summary is transmitted to the country's authorities. In this PIN, the main features of the Board's discussion are described. 
enterprises formerly under the Enterprise Restructuring Agency (ERA) was leased to a foreign investor. In the agricultural sector, the process of land registration and consolidation of landholdings was progressing. In the public administration, overmanning was reduced through cuts in employment. In tax administration, a revised customs code was drawn up and a modem income and profits tax introduced. Last, but not least, the govemment began implementing an anti-corruption strategy.

The Kosovo crisis is a serious threat to macroeconomic stability and reform. Since the NATO bombing campaign began, over 460,000 refugees have flooded into Albania, augmenting the local population by some 14 percent. The large refugee population places a considerable strain on the social and political infrastructure, as well as on the budget, and stretches administrative capacity of the government with attendant risks of a breakdown in law and order. At the same time, humanitarian and military supplies are clogging Albania's ports, crowding out commercial imports.

Nevertheless, the authorities have shown continuing commitment to reform and stabilization. With the budget facing large, uncertain costs associated with the refugees, the authorities announced a freeze on public investment and a postponement of the 10 percent civil service pay rise planned for April 1. They only began to lift the spending restrictions when the international community began to make firm pledges of budgetary assistance. The exchange rate has remained broadly stable against the U.S. dollar. At the same time, some important structural measures have been implemented: Parliament passed the amended customs code, which is now being implemented; the government selected a foreign buyer for NCB; and the government has liquidated two more former-ERA enterprises.

With international donors and creditors making pledges at a meeting on May 26, 1999 to finance refugee-related expenditures on highly concessional terms, the crisis need not have an adverse impact on growth and inflation. Albania has negligible official trade with the Federal Republic of Yugoslavia, and supply side disruptions are likely to be offset by increased production elsewhere. The IMF staff projects that growth could continue at 8 percent in 1999, assuming that social stability can continue to be maintained and the capacity problem of the ports is solved quickly. A temporary increase in food prices is possible-although a decline in inflation to zero in the year to May 1999 suggests this has not happened so far-but would still be expected to leave inflation below the authorities' end-year target of 7 percent. Uncertainty in the outlook for growth and inflation has, however, increased substantially.

The Kosovo crisis apart, Albania still faces tremendous development problems. Despite rapid growth in the early years of transition, per capita GNP is only about US $\$ 800$. Basic structural deficiencies in the economy run deep. The financial system is rudimentary; the tax base is inadequate; communications are hampered by a weak infrastructure; and waste and inefficiency are considerable in the public utilities. Corruption and organized crime are recognized problems and administrative capacity is weak. The internal and external security situation undermines investor confidence. 


\section{Executive Board Assessment}

Directors commended the authorities for their success in restoring macroeconomic stability following the 1997 disturbances. Directors noted that output had rebounded from its earlier losses, inflation had declined significantly, and foreign reserves had risen to a reasonably comfortable level. The authorities' success stemmed from their firm implementation of prudent macroeconomic policies and progress in structural reforms, including in the key areas of privatization, the financial system, and the agricultural sector.

Directors praised the authorities' response to the formidable challenges posed by the Kosovo crisis. The flood of refugees into Albania since the crisis erupted in late March has placed tremendous strain on the social and economic infrastructure, as well as on the budget and balance of payments. Nevertheless, the authorities have persevered with their stabilization and reform efforts. Directors considered that, with sufficient external support, Albania should be able to meet its macroeconomic program objectives in 1999 and continue to address the still severe development problems facing the country. Noting that the transition process was far from complete, they underscored the importance of maintaining the momentum of structural reform and of efforts to improve governance as necessary conditions for sustained rapid growth. In this connection, Directors were encouraged by the recent actions and statements of the authorities.

Regarding fiscal policy, Directors noted that donor financing of Kosovo-related expenses should enable the government to keep within its domestic budget borrowing limits in 1999. At the same time, they considered that the government should intensify its efforts to raise tax collections, which were low in relation to GDP, in order to create room for increased government spending on infrastructure investment and for social purposes without compromising the process of fiscal consolidation. Directors considered that the achievement of the desired increase in tax revenues would require full implementation of the customs code and strengthened measures to combat fraud and smuggling, as well as a broadening of the tax base, especially in the agricultural sector. They also encouraged the authorities to continue their efforts to reduce expenditures where possible, notably through civil service reform. Directors stressed that it is critical for the authorities to observe the highest standards of transparency in accounting for expenditures and funding connected with the Kosovo crisis. In this regard, they welcomed the authorities' intention to place the financial assistance provided by the donor community in a separate account in the Savings Bank, and to make information on related transactions available to the public.

Directors observed that the Bank of Albania's pragmatic handling of monetary policy since the disturbances of 1997 had been rewarded with price stability. They agreed that, if inflation remained low and the exchange rate stable, there would be scope to cut interest rates further. There should also be room within the monetary program for an expansion of private credit, but such expansion would only be feasible and desirable if bank restructuring efforts were accelerated and bank supervision strengthened. Directors considered that better bank supervision would also be required before the Bank of Albania could begin to use indirect 
monetary instruments more fully. They agreed that the authorities should continue to maintain a market-determined exchange rate system.

Directors urged the authorities to maintain the momentum of structural reforms. Having brought the National Commercial Bank to the point of sale, they advised the authorities to finalize the sale quickly, and to accelerate plans for privatizing the Savings Bank. The commendable progress so far in agricultural land registration should be built upon and, if possible, accelerated in order to develop the land market and consolidate land holdings. Restructuring efforts in the telecommunications, petroleum, and mining sectors should be implemented vigorously, and the management and governance problems of the utilities, particularly in the electricity sector, should be urgently addressed.

Directors stressed the need for utmost vigilance to ensure that the strains created by the Kosovo crisis did not weaken governance. They urged the govemment to continue to implement its anti-corruption program and the necessary reforms in the customs administration, the judiciary, and public administration. Directors noted that the pyramid scheme episode was close to resolution, and urged that the remaining steps be completed quickly and transparently. They welcomed, as an indication of the authorities' commitment to transparency, their intention to publish the memorandum of economic and financial policies and their wish to participate in the pilot project for the release of staff reports for the Article IV consulta:ion.

Directors encouraged the authorities to continue their efforts to create an open and liberal trade and exchange system, and welcomed the recent reduction of the maximum tariff rate and the authorities' plans to reduce tariffs further in the future.

Directors recognized that Albania's balance of payments position would likely worsen in 1999, reflecting the consequences of the Kosovo crisis, which had raised import demand, weakened export growth, and diminished the prospects for foreign direct investment. They indicated that, in view of the considerable economic and social strains on Albania resulting from the crisis, generous financial support on highly concessional terms from the international community would be required to enable the authorities to achieve the ambitious objectives of their economic program. Some Directors were of the view that the international financial institutions should stand ready to increase their support quickly in order to close any financing gap that. might emerge on account of the Kosovo crisis.

Directors recommended that the authorities endeavor to improve the quality and coverage of economic statistics. They encouraged them to seek technical assistance from bilateral and multilateral sources to supplement their own technical resources.

\footnotetext{
Public Information Notices (PINs) are issued, (I) at the request of a member country, following the conclusion of the Article IV consultation for countries seeking to make known the views of the IMF to the public. This action is intended to strengthen IMF surveillance over the economic policies of member countries by increasing the transparency of the IMF's assessment of these policies; and (ii) following policy discussions in the Executive Board at the decision of the Board.
} 
Albania: Selected Economic Indicators

\begin{tabular}{|c|c|c|c|c|}
\hline & 1996 & 1996 & 1997 & 1998 \\
\hline & \multicolumn{4}{|c|}{ (Percent change) } \\
\hline Real GDP & 8.9 & 9.1 & -7.0 & 8.0 \\
\hline Retail prices (period average) & 7.8 & 12.7 & 32.1 & 20.9 \\
\hline \multirow[t]{2}{*}{ Retail prices (during period) } & 6.0 & 17.4 & 42.1 & 8.7 \\
\hline & \multicolumn{4}{|c|}{ (In percent of GDP) } \\
\hline \multicolumn{5}{|l|}{ Fiscal sector } \\
\hline Revenues & 24.1 & 18.6 & 16.9 & 20.3 \\
\hline Expenditures & 34.3 & 30.3 & 29.4 & 30.7 \\
\hline Overall deficit & 10.3 & 11.7 & 12.6 & 10.4 \\
\hline Domestically financed deficit & 6.6 & 10.6 & 10.8 & 6.4 \\
\hline Public debt & 55.5 & 59.9 & 71.3 & 59.4 \\
\hline Domestic 1/ & 25.1 & 30.7 & 35.8 & 32.9 \\
\hline External & 30.4 & 29.2 & 35.6 & 26.5 \\
\hline \multicolumn{5}{|l|}{ Monetary indicators } \\
\hline Broad money growth (in percent) & 51.8 & 43.8 & 28.4 & 19.9 \\
\hline Growth in private sector credit (in percent) & 15.9 & 30.5 & 19.0 & 15.8 \\
\hline \multirow[t]{2}{*}{ Interest rate (3 months deposits) } & 10.0 & 18.5 & 26.0 & 16.5 \\
\hline & \multicolumn{4}{|c|}{ (In millions of U.S dollars) } \\
\hline \multicolumn{5}{|l|}{ External sector } \\
\hline Current account balance $2 /$ & -176 & -245 & -276 & -187 \\
\hline (in percent of GDP) & -7.3 & -9.1 & -12.1 & -6.1 \\
\hline Trade balance & -474 & -692 & -519 & -621 \\
\hline (in percent of GDP) & -19.6 & -25.7 & -22.7 & -20.4 \\
\hline Gross international reserves & 240 & 275 & 306 & 384 \\
\hline (in months of imports of goods and services) & 3.5 & 3.1 & 4.5 & 4.7 \\
\hline \multicolumn{5}{|l|}{ Memorandum items: } \\
\hline Nominal GDP (in millions of leks) & 224,745 & 280,998 & 341,716 & 460,631 \\
\hline Nominal GDP (in millions of U.S. dollars) & 2.422 & 2,689 & 2,284 & 3,047 \\
\hline
\end{tabular}

Sources: Data provided by the authorities; and IMF staff estimates.

$1 /$ Including bonds for bank restructuring.

2/ Excluding official transfers.

CInternational Monetary Fund. Not for Redistribution 